University of Nebraska - Lincoln

DigitalCommons@University of Nebraska - Lincoln

US Department of Energy Publications

U.S. Department of Energy

2004

\title{
Chromium Speciation and Mobility in a High Level Nuclear Waste Vadose Zone Plume
}

John M. Zachara

Pacific Northwest National Laboratory, john.zachara@pnl.gov

Calvin Ainsworth

Pacific Northwest National Laboratory

Gordon Brown Jr.

Stanford University

Jeffery Catalano

Stanford University

James Mckinley

Pacific Northwest National Laboratory, james.mckinley@pnl.gov

See next page for additional authors

Follow this and additional works at: https://digitalcommons.unl.edu/usdoepub

Part of the Bioresource and Agricultural Engineering Commons

Zachara, John M.; Ainsworth, Calvin; Brown, Gordon Jr.; Catalano, Jeffery; Mckinley, James; Qafoku, Odeta; Smith, Steven; Szecsody, James; Traina, Sam; and Warner, Jeffrey, "Chromium Speciation and Mobility in a High Level Nuclear Waste Vadose Zone Plume" (2004). US Department of Energy Publications. 255.

https://digitalcommons.unl.edu/usdoepub/255

This Article is brought to you for free and open access by the U.S. Department of Energy at DigitalCommons@University of Nebraska - Lincoln. It has been accepted for inclusion in US Department of Energy Publications by an authorized administrator of DigitalCommons@University of Nebraska - Lincoln. 


\section{Authors}

John M. Zachara, Calvin Ainsworth, Gordon Brown Jr., Jeffery Catalano, James Mckinley, Odeta Qafoku, Steven Smith, James Szecsody, Sam Traina, and Jeffrey Warner 


\title{
doi:10.1016/S0016-7037(03)00417-4
}

\section{Chromium Speciation and Mobility in a High Level Nuclear Waste Vadose Zone Plume}

\author{
John M. Zachara, ${ }^{*}, 1$ Calvin C. Ainsworth, ${ }^{1}$ Gordon E. Brown Jr., ${ }^{2}$ Jeffrey G. Catalano, ${ }^{2}$ James P. McKinley, ${ }^{1}$ \\ Odeta QAfoku, ${ }^{1}$ Steven C. Smith, ${ }^{1}$ James E. Szecsody, ${ }^{1}$ Sam J. Traina, ${ }^{3}$ and Jefrrey A. Warner ${ }^{2}$ \\ ${ }^{1}$ Pacific Northwest National Laboratory, Richland, WA 99352 USA \\ ${ }^{2}$ Stanford University, Stanford, CA 94305 USA \\ ${ }^{3}$ University of California, Merced, Merced, CA 95433 USA
}

(Received August 28, 2002; accepted in revised form May 1, 2003)

\begin{abstract}
Radioactive core samples containing elevated concentrations of $\mathrm{Cr}$ from a high level nuclear waste plume in the Hanford vadose zone were studied to asses the future mobility of $\mathrm{Cr}$. $\mathrm{Cr}(\mathrm{VI})$ is an important subsurface contaminant at the Hanford Site. The plume originated in 1969 by leakage of self-boiling supernate from a tank containing REDOX process waste. The supernate contained high concentrations of alkali $(\mathrm{NaOH}$ $\approx 5.25 \mathrm{~mol} / \mathrm{L})$, salt $\left(\mathrm{NaNO}_{3} / \mathrm{NaNO}_{2}>10 \mathrm{~mol} / \mathrm{L}\right)$, aluminate $\left[\mathrm{Al}(\mathrm{OH})_{4}^{-}=3.36 \mathrm{~mol} / \mathrm{L}\right], \mathrm{Cr}(\mathrm{VI})(0.413 \mathrm{~mol} / \mathrm{L})$, and ${ }^{137} \mathrm{Cs}^{+}\left(6.51 \times 10^{-5} \mathrm{~mol} / \mathrm{L}\right)$. Water and acid extraction of the oxidized subsurface sediments indicated that a significant portion of the total $\mathrm{Cr}$ was associated with the solid phase. Mineralogic analyses, $\mathrm{Cr}$ valence speciation measurements by X-ray adsorption near edge structure (XANES) spectroscopy, and small column leaching studies were performed to identify the chemical retardation mechanism and leachability of Cr. While $\mathrm{X}$-ray diffraction detected little mineralogic change to the sediments from waste reaction, scanning electron microscopy (SEM) showed that mineral particles within $5 \mathrm{~m}$ of the point of tank failure were coated with secondary, sodium aluminosilicate precipitates. The density of these precipitates decreased with distance from the source (e.g., beyond $10 \mathrm{~m}$ ). The XANES and column studies demonstrated the reduction of 29-75\% of the total $\mathrm{Cr}$ to insoluble $\mathrm{Cr}$ (III), and the apparent precipitation of up to $43 \%$ of the $\mathrm{Cr}(\mathrm{VI})$ as an unidentified, non-leachable phase. Both $\mathrm{Cr}(\mathrm{VI})$ reduction and $\mathrm{Cr}(\mathrm{VI})$ precipitation were greater in sediments closer to the leak source where significant mineral alteration was noted by SEM. These and other observations imply that basic mineral hydrolysis driven by large concentrations of $\mathrm{OH}^{-}$in the waste stream liberated $\mathrm{Fe}(\mathrm{II})$ from the otherwise oxidizing sediments that served as a reductant for $\mathrm{CrO}_{4}^{2-}$. The coarse-textured Hanford sediments contain silt-sized mineral phases (biotite, clinochlore, magnetite, and ilmenite) that are sources of Fe(II). Other dissolution products (e.g., $\mathrm{Ba}^{2+}$ ) or $\mathrm{Al}(\mathrm{OH})_{4}^{-}$present in the waste stream may have induced $\mathrm{Cr}(\mathrm{VI})$ precipitation as $\mathrm{pH}$ moderated through mineral reaction. The results demonstrate that a minimum of $42 \%$ of the total $\mathrm{Cr}$ inventory in all of the samples was immobilized as $\mathrm{Cr}(\mathrm{III})$ and $\mathrm{Cr}(\mathrm{VI})$ precipitates that are unlikely to dissolve and migrate to groundwater under the low recharge conditions of the Hanford vadose zone. Copyright (C) 2004 Elsevier Ltd
\end{abstract}

\section{INTRODUCTION}

Chromate $\left(\mathrm{CrO}_{4}^{2-}\right)$ is a significant and common groundwater contaminant in the U.S. and other industrialized nations. It finds its way into groundwater through waste disposal from industrial activities including electroplating, tanning, wood pulp production, electricity generation (cooling water treatment, fly ash disposal), ore and petroleum refining (Palmer and Wittbrodt, 1991), and high-level nuclear waste as described here. The present drinking water standard for $\mathrm{CrO}_{4}^{2-}$ is $10^{-6} \mathrm{~mol} / \mathrm{L}$ (http://www.epa.gov/SaFewater/ $\mu$ L.html).

Both the toxicity and subsurface transport behavior of $\mathrm{Cr}$ depend strongly on its valence. Hexavalent $\mathrm{Cr}[\mathrm{Cr}(\mathrm{VI})]$ exists primarily in the form of $\mathrm{CrO}_{4}^{2-}$, which is relatively soluble over much of the environmental $\mathrm{pH}$ range. $\mathrm{CrO}_{4}^{2-}$ is a strong oxidant and is toxic to a variety of plants and animals (Abbasi and Soni, 1984; Ono, 1988; Paschin et al., 1983). Chromate is poorly adsorbed by amphoteric mineral surfaces at circumneutral $\mathrm{pH}$ and above (Zachara et al., 1987; Zachara et al., 1989) and can exhibit high subsurface mobility under these conditions (Kent et al., 1995). At intermediate and low redox potentials, $\mathrm{Cr}(\mathrm{VI})$

* Author to whom correspondence should be addressed (john.zachara@pnl.gov). is reducible to $\mathrm{Cr}(\mathrm{III})\left(\mathrm{E}^{\circ} \approx 1.3 \mathrm{~V}\right.$; see Palmer and Wittbrodt, 1991 for review). Both aqueous (Buerge and Hug, 1997; Eary and Rai, 1988; Pettine et al., 1998; Sedlak and Chan, 1997) and solid Fe(II) (Brigatti et al., 2000b; Peterson et al., 1996; Peterson et al., 1997a, 1997b) forms are effective reductants of $\mathrm{CrO}_{4}^{2-}$, with rates dependent on $\mathrm{pH}$ and the identity and surface/thermodynamic properties of the solid phase. $\mathrm{Cr}(\mathrm{III})$ is relatively non-toxic, and forms sparingly soluble hydroxide precipitates and solid solutions with $\mathrm{Fe}(\mathrm{OH})_{3}$ at circumneutral $\mathrm{pH}$ and above. $\mathrm{Cr}(\mathrm{III})$ is weakly mobile in groundwater because of low solubility, and precipitated $\mathrm{Cr}(\mathrm{OH})_{3}$ exhibits slow reaction kinetics with molecular oxygen (Rai et al., 1986). The differential geochemical and biologic behavior of $\mathrm{Cr}(\mathrm{VI})$ and $\mathrm{Cr}$ (III) has led to the use of in-situ reduction and precipitation as a remedial treatment for $\mathrm{CrO}_{4}^{2-}$ groundwater contamination (Fruchter et al., 2000).

Chromate is a significant groundwater contaminant at the U.S. Department of Energy (DOE) Hanford Site in southeastern WA (Poston et al., 2001) where Pu was produced during WWII and the cold war, and where DOE's largest inventory of legacy wastes remain. Chromate used as a corrosion inhibitor was released to disposal cribs in coarse-textured, Pleistoceneage flood deposits in the Columbia River corridor. Chromate shows little or no adsorptive retardation in these sediments and 
groundwater contamination plumes have resulted that discharge $\mathrm{CrO}_{4}^{2-}$ to the Columbia River (Poston et al., 2001), imperiling spawning salmon. Further from the Columbia River (ca 5-7 km), $\mathrm{kL}$ of $\mathrm{CrO}_{4}^{2-}$ containing high-level nuclear waste (HLW) from the REDOX separation process have leaked to the 70 m deep vadose zone as a result of multiple single-shell tank failures in the $S$-SX tank farm (Jones et al., 2000). Significant concern exists for the migration of these HLW chemical and radioactive contaminants to the groundwater that lies beneath the vadose zone and that eventually discharges to the Columbia River.

Recently, a slant borehole was placed beneath tank SX-108 at Hanford that intersected and sampled a vadose zone contaminant plume of HLW (Serne et al., 2001a, 2001b). The plume originated from the leakage of approximately $380 \mathrm{~kL}$ of caustic, hot $\left(>100^{\circ} \mathrm{C}\right)$ REDOX tank brine in 1969 that contained approximately $89 \mathrm{kCi}$ of ${ }^{137} \mathrm{Cs}, 250 \mathrm{~kg}$ of $\mathrm{CrO}_{4}^{2-}$, and other chemical and radioactive contaminants (Jones et al., 2000). Some of the retrieved core samples were the most radioactive geomedia ever brought to the surface at Hanford. Characterization measurements of the core samples (Serne et al., 2001a, 2001b) indicated an unusual pattern of apparent chemical attenuation of $\mathrm{CrO}_{4}^{2-}$ that required explanation for risk assessment. In this communication we present results of XANES spectroscopy measurements, mineralogic analyses, and leaching studies on these contaminated sediments performed with the objective of defining a conceptual chemical model for $\mathrm{CrO}_{4}^{2-}$ retardation under saline, alkaline conditions. Our results provide insights on the future in-ground geochemical behavior of $\mathrm{Cr}$ at this site, and provide a basis for informed corrective and remedial action decisions in the Hanford tank farms.

\section{MATERIAL AND METHODS}

\subsection{Site Characteristics}

Waste Management Area (WMA) $S$-SX is a high-level waste tank farm in the 200 West Area of the U.S. DOE Hanford Site in southcentral Washington State (Fig. 1). The SX tank farm, the origin of samples for this study, contains 15 single-shell, high-level waste tanks, each with $3785 \mathrm{~kL}$ (1000 kgal) capacity. The tanks are $23.5 \mathrm{~m}$ in diameter, $13.8 \mathrm{~m}$ high, and tank bottoms lie at a depth of $15.7 \mathrm{~m}$ below ground surface. The SX waste tanks received self-boiling waste solutions from the Reduction-Oxidation (REDOX) Plant at Hanford in the mid 1950s. The REDOX process was used to recover Pu from irradiated nuclear fuels. Hexavalent $\mathrm{Cr}[\mathrm{Cr}(\mathrm{VI})]$ in the form potassium dichromate was used as an oxidant in the REDOX process to manipulate the valence states of $\mathrm{Pu}$ and $\mathrm{U}$. The REDOX wastes were self-boiling from the radioactive decay of short-lived isotopes (Jones et al., 2000) and the high concentration of ${ }^{137} \mathrm{Cs}^{+}$.

During the 1960s and 1970s nine of the SX tanks developed leaks as a result of the high thermal load from waste boiling and the caustic nature of the wastes. Model calculations performed by Pruess et al. (2001) and White et al. (2001) suggested that these wastes were discharged into vadose zone sediments that were elevated in temperature (to $100^{\circ} \mathrm{C}$ ) and desiccated to depths of $20 \mathrm{~m}$ or more below the tanks as a result of the thermal load from the boiling tank wastes. One of the largest single tank leaks was from SX-108, that discharged an estimated $57760 \mathrm{~L}$ of hot, self-concentrated (from boiling) REDOX waste. The leaked SX-108 tank waste, Table 1 (estimated by Jones et al., 2000 and Lichtner, 2001), contained high concentrations of salt, base, $\mathrm{Cr},{ }^{137} \mathrm{Cs}^{+},{ }^{99} \mathrm{Tc}(\mathrm{VII})$, and other radioactive and chemical constituents. The valence of $\mathrm{Cr}$ in the REDOX waste supernatant was believed to be $\mathrm{Cr}(\mathrm{VI})$, with residual $\mathrm{Cr}(\mathrm{III})$ present in oxide form in sludge at the tank bottom. However, valence-specific measurements for Cr were not performed on REDOX tank wastes in the 1950s and 1960s.
Personnel within Hanford's Tank Farm Vadose Characterization Project collected and analyzed subsurface samples beneath tank SX108, and alongside nearby tank SX-115 in 1999 and 2000 to assess the depth distribution and fate of the tank waste contaminants (Serne et al., 2001a, 2001b). The characterization activity was driven by evidence that solutes in the tank waste supernate $\left(\mathrm{Na}, \mathrm{NO}_{3},{ }^{99} \mathrm{Tc}\right)$ had migrated to groundwater through the vadose zone. Samples from three boreholes were examined. In this communication we focus on the most complete borehole (SX-108) as well as two samples from another borehole (41-09-39) for comparison and verification (Fig. 2). The SX-108 borehole was unique at Hanford; it was placed off-vertical and slanted to allow the collection of materials from directly beneath the leaked tank.

\subsection{Sediment Collection and Analysis}

Collection and preliminary analyses of sediments from the SX-108 slant and 41-09-39 boreholes are discussed elsewhere (Serne et al., 2001a, 2001b). The specific samples investigated in detail here were SX-108 sediments 3A, 6A, 7A, 8A, 9A, 13A, 14A and 41-09-39 sediments $6 \mathrm{AB}$ and $7 \mathrm{ABC}$. All of the samples contained appreciable levels of adsorbed ${ }^{137} \mathrm{Cs}\left(10^{5}\right.$ to $\left.10^{8} \mathrm{pCi} / \mathrm{g}\right)$ that made sample handling difficult. Subsamples of the field-moist material were air-dried to a constant weight and sieved to pass a $2 \mathrm{~mm}$ mesh. Gravels greater than $2 \mathrm{~mm}$ were removed from the air-dried material during the sieving process. The sieved material was thoroughly mixed to obtain a homogeneous sample.

Serne et al. (2001a, 2001b) used water and hot $8 \mathrm{~N} \mathrm{HNO}_{3}$ extractions to characterize soluble and total $\mathrm{Cr}$ concentrations in the SX sediments. The methods for those extractions are briefly described here because their data is used for comparative purposes. Water-soluble inorganic constituents were determined using a 1:1 sediment-to-deionized water extract method (Rhoades, 1996). This method was chosen because the sediment was too dry to easily extract vadose zone porewater. The extracts were prepared by adding an exact weight of deionized water to $60 \mathrm{~g}$ of sediment. The mass of deionized water needed to achieve a 1:1 mass ratio was calculated based on the moisture content of the sediment. The appropriate amount of deionized water was added to screw cap jars containing the sediment samples. The jars were sealed and briefly shaken by hand, then placed on a mechanical orbital shaker for $1 \mathrm{~h}$. The samples were allowed to settle until the supernate was clear. The supernate was decanted and separated into unfiltered aliquots for conductivity and $\mathrm{pH}$ determinations, and filtered aliquots $(0.45 \mu \mathrm{m})$ for anion (e.g., Cr), cation, carbon, and radionuclide analyses. Total acidextractable $\mathrm{Cr}$ was determined by contacting $20 \mathrm{~g}$ of oven-dried sediment with $8 \mathrm{~N} \mathrm{HNO}_{3}$ at a ratio of $\sim 5$ parts acid to 1 part sediment. The slurries were heated to $\sim 80^{\circ} \mathrm{C}$ for several hours and then the fluid was separated by centrifugation and filtration $(0.2 \mu \mathrm{m})$. The acid extracts were analyzed for major cations and trace metals using inductively coupled plasma (ICP) and inductively coupled plasma-mass spectrometer (ICP-MS) techniques, respectively. The acid digestion procedure is based on U.S. Environmental Protection Agency (EPA) SW846 Method 3050B that can be accessed on-line at http://www.epa/ gove/epaoswer/hazwaste/test/sw846.htm.

The total Cr composition of the sediments was determined by energy-dispersive X-ray fluorescence spectroscopy (XRF) using a $\mathrm{Zr} / \mathrm{Fe}$ target. All spectral measurements were collected from finely ground powders. XRF analysis of SX-108 sediments 7A, 8A, and 13A, and 41-09-39 sediments 7ABC, and 6AB were performed in triplicate; all other sediment XRF analyses were determined on single samples. Error values for single sediment analyses were calculated based on $5 \%$ uncertainty in the XRF standards plus one standard deviation of the net $\mathrm{X}$-ray counts. Values associated with triplicated sediments are reported as the mean \pm the standard deviation.

$\mathrm{X}$-ray diffraction (XRD) analyses were performed on the contaminated samples using a Scintag diffractometer with $\mathrm{Cu} \mathrm{K}_{\alpha}$ radiation and a thermoelectrically cooled detector. Sediment samples were crushed to a powder and placed in zero-background cells for XRD analysis as random mounts. Samples for SEM analyses were prepared by sprinkling sediment grains directly onto sticky tape on a 1-inch SEM stub. A glass cylinder was rolled over the dispersed sediment to firmly fix it to the tape. This step caused some disintegration of agglomerated clasts and mica flakes. The sediment was sputter-coated with carbon for conductivity; some individual clasts nevertheless exhibited poor con- 


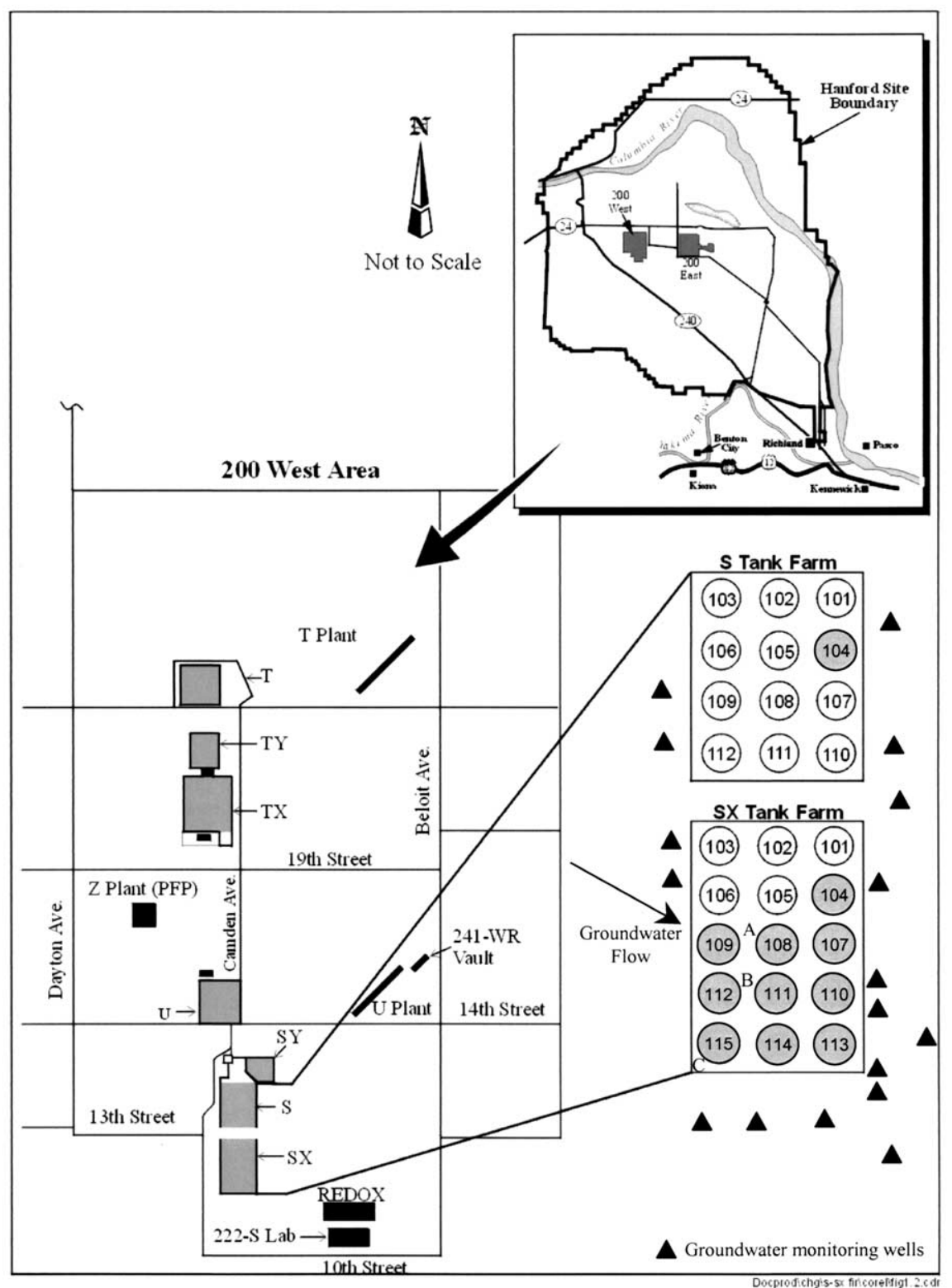

Fig. 1. Location of Waste Management Area (WMA) S-SX at the Hanford site and identification of single shell tanks that show evidence for leakage (gray). Monitoring wells and groundwater flow direction as noted. $\mathrm{A}=\mathrm{SX}-108$ core, $\mathrm{B}=$ 41-09-39 core, and $\mathrm{C}=\mathrm{SX}-115$.

ductivity from sample charging. Samples were imaged using a JEOL 840 SEM. Images were captured using a Gatan CCD device and elemental analysis was via an Oxford energy dispersive spectrometer (EDS). Some samples were screened for SEM analyses using a Molecular Dynamics Storm autoradiography system.

\subsection{XANES Analyses}

Sediment samples from the S-SX tank farms were packed in Teflon® sample holders sealed with 10 mil Kapton ${ }^{\circledR}$ tape, and then heat-sealed in polyethylene bags. They were shipped from PNNL to the Stanford Synchrotron Radiation Laboratory (SSRL) for XANES spectroscopy analysis. The volume of each sample examined was approximately 15 $\mathrm{mm} \times 2 \mathrm{~mm} \times 1 \mathrm{~mm}$ (the volume illuminated by the X-ray beam on a typical 8-pole wiggler beam line at SSRL) and the bulk density of each sample was approximately $1.6 \mathrm{~g} / \mathrm{cm}^{3}$. An Ar-filled Stern-Heald-type
X-ray fluorescence detector (Lytle et al., 1984) or a 13-element Ge detector was used to monitor $\mathrm{Cr} \mathrm{K} \alpha$ fluorescence as a function of incident X-ray energy. A $3 \mu \mathrm{m}$-thickness filter was placed between the sample and the detector to minimize scattering and thus reduce background radiation. The sample container was purged with He before data collection, and He flowed through the sample container during data collection to minimize air scatter, which can be significant for an incident X-ray beam at $\mathrm{Cr} \mathrm{K}$-edge energies.

Cr K-XANES spectra were measured on the Molecular Environmental Science Beam Line (BL 11-2) (Bargar et al., 2001) or a general XAFS beamline (BL 4-3) over the energy range $5900 \mathrm{eV}$ to $6350 \mathrm{eV}$ using a cryogenically cooled $\mathrm{Si}$ (220) double-crystal monochromator in the case of BL 11-2, or a normal $\mathrm{Si}(220)$ double-crystal monochromator in the case of BL 4-3, with the SPEAR ring operating at 60 to 100 $\mathrm{mA}$ electron current and $3 \mathrm{GeV}$ energy. The vertical slit before the monochromator was adjusted to $1 \mathrm{~mm}$ height to enhance energy reso- 
Table 1. Estimated composition of REDOX HLW released from tank 108 to the vadose zone in 1969 (from Jones et al., 2000).

\begin{tabular}{lr} 
Temperature $\left({ }^{\circ} \mathrm{C}\right)$ & 100 \\
$\mathrm{H}_{2} \mathrm{O}$ mole fraction & 0.539 \\
$\mathrm{H}_{2} \mathrm{O}$ weight fraction & 0.304 \\
Solution density $\left(\mathrm{g} / \mathrm{cm}^{3}\right)$ & 2.09 \\
Ionic strength & 18.02 \\
& \\
\hline Primary Chemical & \\
$\quad$ Species & $(\mathrm{mol} / \mathrm{L})$ \\
\hline $\mathrm{Al}(\mathrm{OH})_{4}^{-}$ & 3.36 \\
$\mathrm{~K}^{+}$ & $7.39 \times 10^{-2}$ \\
$\mathrm{Na}^{+}$ & 19.6 \\
$\mathrm{OH}^{-}$ & 5.25 \\
$\mathrm{NO}_{3}^{-}$ & 5.46 \\
$\mathrm{NO}_{2}^{-}$ & 4.42 \\
$\mathrm{Cl}^{-}$ & 0.34 \\
$\mathrm{CO}_{3}^{2-}$ & $3.25 \times 10^{-2}$ \\
$\mathrm{SO}_{4}^{2-}$ & $2.77 \times 10^{-2}$ \\
$\mathrm{CrO}_{4}^{2-}$ & $4.13 \times 10^{-1}$ \\
${ }^{2}{ }^{-} \mathrm{Cs}^{+}$ & $6.51 \times 10^{-5}$ \\
\hline &
\end{tabular}

lution. A step size of $0.15 \mathrm{eV}$ was used in the energy region 5980 to $6010 \mathrm{eV}$, and a step size of $1 \mathrm{eV}$ was used over the energy region 6010 to $6350 \mathrm{eV}$. An integration time of $4 \mathrm{~s}$ was used at each step. Because the samples were thick $(2 \mathrm{~mm})$, and could not be manipulated on site due to the high level of radioactivity, it was not possible to simultaneously collect X-ray fluorescence data from the sample and transmission data from a $\mathrm{Cr}$ metal foil used for energy calibration. However, foil edges were collected within $40 \mathrm{~min}$ of XANES measurements for each sample, and the drift of the monochromator was found to be negligible during this time frame. The first inflection point of the $\mathrm{Cr}$ metal foil edge was set to $5989 \mathrm{eV}$. The deviation from this value was recorded (it was typically around 0.3 to $0.5 \mathrm{eV}$ ), and the sample spectra were calibrated in energy using this inflection point energy value. Two scans of each sample were recorded and averaged. Reduction of polyvalent elements like $\mathrm{Cr}$ can occur in the intense $\mathrm{X}$-ray beam of a synchrotron and must be monitored in these types of experiments. No evidence of beam-induced $\mathrm{Cr}$ (VI) to $\mathrm{Cr}$ (III) reduction was observed over the relatively short time exposures (15 to $20 \mathrm{~min}$ ) necessary to collect the Cr K-XANES spectra on the sediment samples.

The methods of Peterson et al. (1997a) were used to analyze the $\mathrm{Cr}(\mathrm{VI})$ content of the sediments from the intensity of the preedge feature. The sample data (typically two scans) were averaged using the computer code MAVE, which is a subroutine in the XAFS data analysis package EXAFSPAK (George and Pickering, 1993). No dead time corrections were made. The peak of the pre-edge feature was selected as the calibration point in the EXAFSPAK subroutine MCALIB, as this

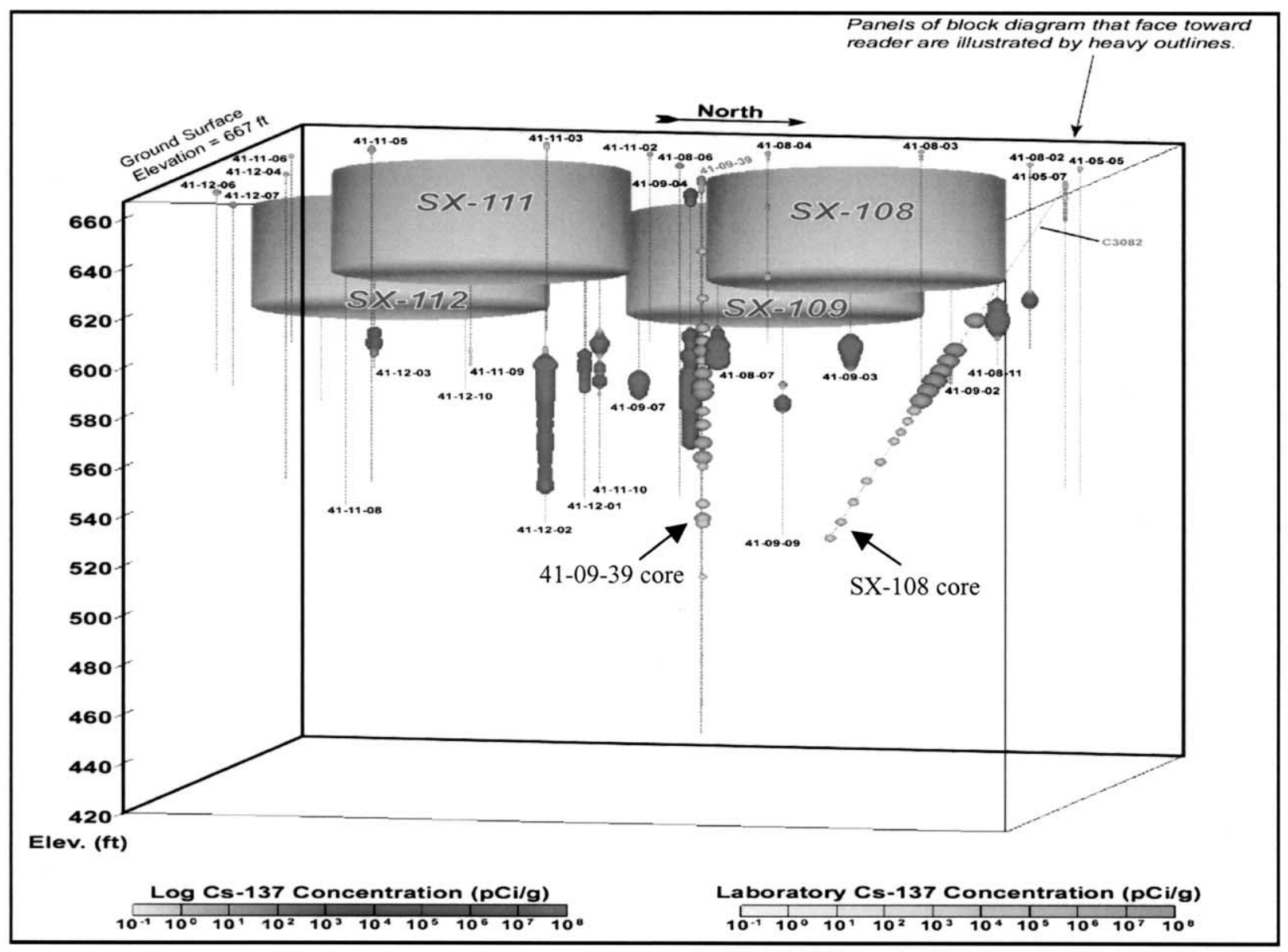

Fig. 2. Schematic of the distribution of boreholes surrounding tanks SX-108, SX-109, SX-111, and SX-112 in the S-SX tank farm. Symbol size denotes ${ }^{137} \mathrm{Cs}$ concentration in $\mathrm{pCi} / \mathrm{g}$. An extensive series of dry boreholes surrounding the tanks is monitored for in-situ ${ }^{137} \mathrm{Cs}$ concentration by downhole spectral gamma logging. Subsurface samples from only two of these (41-09-39 and SX-108) have been collected for laboratory study. Borehole SX-108 retrieved the best, most continuous sample series 
a. Porewater $\mathrm{Na}$ and Nitrate

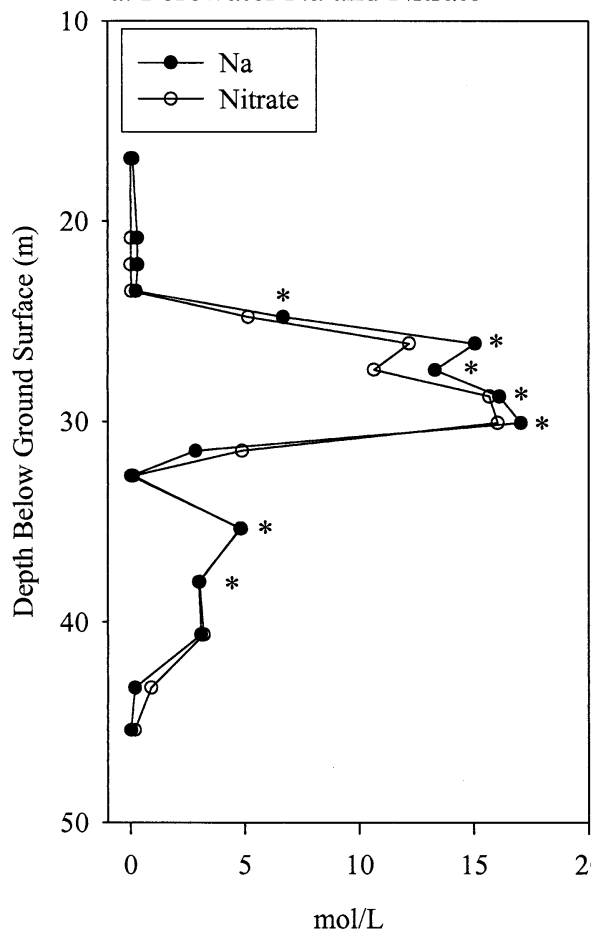

b. Water Extractable and Sorbed $\mathrm{Cr}$

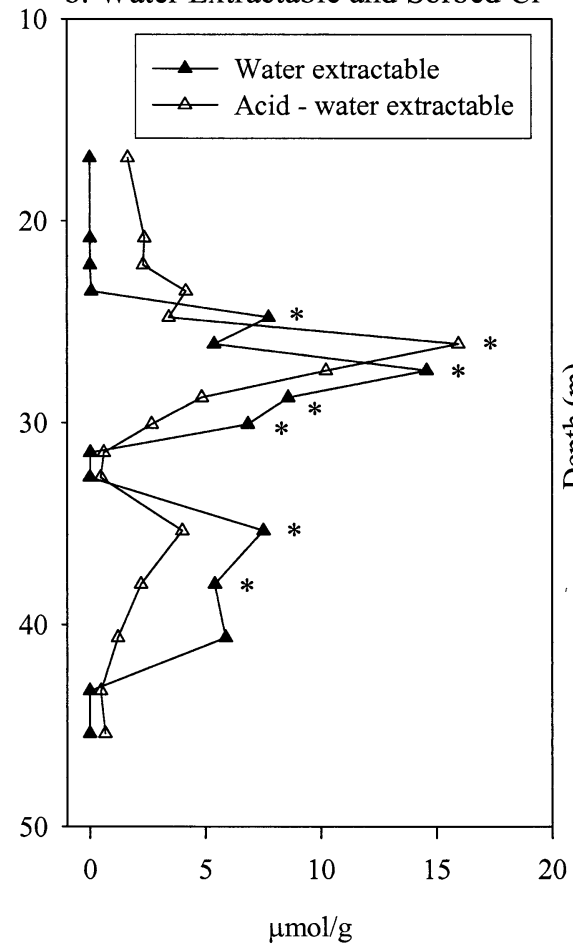

c. In-situ Temperature

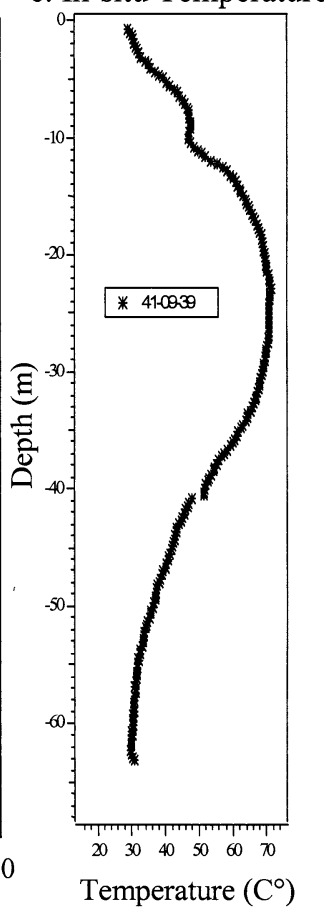

* Used in XAS studies

Fig. 3. Solute concentration profiles in core samples from the $\mathrm{SX}-108$ borehole, a.) $\mathrm{Na}$ and $\mathrm{NO}_{3}$ measured by water extraction and reported as pore water concentrations, and b.) water and acid-water extractable (sorbed) $\mathrm{Cr}$ reported as mass normalized concentrations. In-situ temperature, c.) measured in the nearby 41-09-39 borehole. Data from (Serne et al., 2001a, 2001b).

feature's position should not have changed during the experiment. The position observed was then shifted by the amount of offset measured in the $\mathrm{Cr}$ foil (for example, if the feature occurred at $5992.86 \mathrm{eV}$, and the $\mathrm{Cr}$ foil edge was $0.38 \mathrm{eV}$ low, the data were shifted by $+0.38 \mathrm{eV}$, resulting in a preedge position of $5993.24 \mathrm{eV}$ ). The average preedge peak position for all eight samples was found to be $5993.3 \pm 0.1 \mathrm{eV}$.

The averaged data were then analyzed using the EXAFSPAK subroutine PROCESS by background subtraction using a polynomial preedge fit of the data up to $5960 \mathrm{eV}$. A spline was then fit to the data from $6005 \mathrm{eV}$ to the end of the data (approximately $6350 \mathrm{eV}$ ). A third-order spline with two regions was used to fit this region of the spectrum, with a $k^{4}$ weighting. The normalization point for the edge jump was set at $6025 \mathrm{eV}$. The data were normalized on the $6025 \mathrm{eV}$ spline point and output into an ASCII format. The preedge features of these normalized spectra were then analyzed using the program Grams/ 32 , where a maximum search was performed, yielding the preedge peak height and position.

\subsection{Cr Leaching from Columns}

Column experiments were conducted to determine the extent and rate of $\mathrm{Cr}(\mathrm{VI})$ release from S-SX sediments. The high radioactivity of the samples required the use of small columns to minimize dose to laboratory personnel. Approximately $2 \mathrm{~g}$ of air-dried sediments from each sample (SX-108 7A, SX-108 8A, 41-09-39 6AB, and 41-09-39 $7 \mathrm{ABC}$ ) were packed into $3.1 \mathrm{~cm}$ length by $0.78 \mathrm{~cm}$ diameter polypropylene columns. The columns were then connected to a peristaltic pump on one side, and a fraction collector on the other. Before columns were connected to a leaching solution, approximately $10 \mathrm{~mL}$ of pure $\mathrm{CO}_{2}$ gas was injected through the columns to displace air from sediment pore space. A uniform movement of the leaching solution through the packed air-dried sediments was observed.
Sediment columns were leached with $0.5 \mathrm{~mol} / \mathrm{L} \mathrm{NaNO}_{3}$ at a flow rate of $0.1 \mathrm{~mL} / \mathrm{min}$. This flow rate gave an approximate residence time within the column of 6 min. Effluent samples were collected every 6 min (at approximate 1 pore volume increments) and their mass determined to compute flow rate. After 16-25 pore volumes, electrolyte inflow was stopped for $19 \mathrm{~h}$ and then leaching was continued for another 10 pore volumes. Columns were flushed at $0.1 \mathrm{~mL} / \mathrm{min}$ with 1.0 $\mathrm{mol} / \mathrm{L} \mathrm{NaNO}_{3}$ after all the leachates were collected, and the electrical conductivity monitored to estimate conservative tracer breakthrough. The columns were leached with deionized water, and then weighed to determine the pore space through the mass difference of the wet and air-dried sediments. The $\mathrm{NaNO}_{3}$ leachates $(0.2 \mu \mathrm{m}$ filtered $)$ were analyzed for $\mathrm{Cr}(\mathrm{VI})$ using the diphenylcarbizide colorimetric method $(540 \mathrm{~nm})$ (Barlett and James, 1996).

\section{RESULTS}

\subsection{Contaminant Distribution}

Chemical analyses of the borehole samples identified a welldefined vadose zone plume of $\mathrm{Na}-\mathrm{NO}_{3}$ and $\mathrm{Cr}$ (Fig. 3) occurring within the central and lower Hanford formations. The distribution of ${ }^{99} \mathrm{Tc}$ was almost identical to $\mathrm{NaNO}_{3}$ albeit at lower concentration $\left(<1.0-6.86 \times 10^{-6} \mathrm{~mol} / \mathrm{L}\right.$, data not shown). Chemical data from numerous waste site locations indicate that $\mathrm{NO}_{3}^{-}$and ${ }^{99} \mathrm{Tc}\left(\right.$ as $\mathrm{TcO}_{4}^{-}$) are freely mobile in the oxidized Hanford vadose zone. The characterization data suggest some retardation of $\mathrm{Cr}$ migration as compared to $\mathrm{NO}_{3}^{-}$and ${ }^{99}$ Tc. An attenuation mechanism was also implied by $8 \mathrm{~N}$ 
Table 2. Cr concentrations and distribution coefficients in SX-108 core materials.

\begin{tabular}{|c|c|c|c|c|c|c|c|c|}
\hline$\underline{\text { Sample }}$ & $\begin{array}{c}\text { Depth } \\
\text { (m) }\end{array}$ & $\begin{array}{l}\mathrm{W}^{\mathrm{a}} \\
(\%)\end{array}$ & $\theta^{\mathrm{b}}$ & $\begin{array}{c}\text { Sorbed }^{\mathrm{c}} \\
\mathrm{Cr} \\
(\mu \mathrm{mol} / \mathrm{g})\end{array}$ & $\begin{array}{l}\text { Porewater } \\
\mathrm{Cr}(\mathrm{mol} / \mathrm{L})\end{array}$ & $\begin{array}{c}\begin{array}{c}\mathrm{K}_{\mathrm{d}}{ }^{\mathrm{e}} \\
(\mathrm{mL} / \mathrm{g})\end{array} \\
\end{array}$ & $\mathrm{R}_{\text {-app }}^{\mathrm{f}}$ & $\mathrm{R}_{-\mathrm{adj}^{\mathrm{g}}}^{\mathrm{g}}$ \\
\hline $2 \mathrm{~A}$ & 16.9 & 14.33 & .069 & 1.64 & $4.22 \times 10^{-6}$ & 387 & 8930 & \\
\hline $3 \mathrm{~A}$ & 20.8 & 2.76 & .044 & 2.37 & $5.61 \times 10^{-4}$ & 4.22 & 153 & 280 \\
\hline $4 \mathrm{~A}$ & 22.2 & 2.77 & .044 & 2.31 & $5.35 \times 10^{-4}$ & 4.32 & 157 & \\
\hline $5 \mathrm{~A}$ & 23.5 & 4.69 & .075 & 4.16 & $1.44 \times 10^{-3}$ & 2.88 & 62.4 & \\
\hline $6 \mathrm{~A}^{\mathrm{f}}$ & 24.8 & 3.68 & .059 & 3.42 & $2.11 \times 10^{-1}$ & 0.0162 & 1.44 & 2.27 \\
\hline $7 A^{f}$ & 26.1 & 6.18 & .099 & 16.0 & $8.71 \times 10^{-2}$ & 0.183 & 3.96 & 4.54 \\
\hline $8 \mathrm{~A}^{\mathrm{f}}$ & 27.4 & 6.02 & .096 & 10.2 & $2.42 \times 10^{-1}$ & 0.0422 & 1.70 & 2.76 \\
\hline $9 A^{f}$ & 28.8 & 2.35 & .038 & 4.84 & $3.65 \times 10^{-1}$ & 0.0132 & 1.56 & 3.0 \\
\hline $10 A^{f}$ & 30.1 & 1.91 & .031 & 2.67 & $3.58 \times 10^{-1}$ & 0.0075 & 1.39 & \\
\hline $11 \mathrm{~A}$ & 31.5 & 3.15 & .051 & 0.60 & $5.40 \times 10^{-4}$ & 1.10 & 35.9 & \\
\hline $12 \mathrm{~A}$ & 32.7 & 21.35 & .345 & 0.47 & $1.88 \times 10^{-5}$ & 25.2 & 118 & \\
\hline $13 \mathrm{~A}^{\mathrm{f}}$ & 35.4 & 7.64 & .123 & 4.00 & $9.84 \times 10^{-2}$ & 0.0406 & 1.53 & 2.28 \\
\hline $14 \mathrm{~A}^{\mathrm{f}}$ & 38.0 & 11.95 & .192 & 2.21 & $4.54 \times 10^{-2}$ & 0.0489 & 1.40 & 1.91 \\
\hline $15 \mathrm{~A}$ & 40.6 & 17.42 & .280 & 1.21 & $3.37 \times 10^{-2}$ & 0.0358 & 1.20 & \\
\hline $16 \mathrm{~A}$ & 43.3 & 7.5 & .120 & 0.47 & $5.08 \times 10^{-6}$ & 92.3 & 1231 & \\
\hline $17 \mathrm{~A}$ & 45.4 & 19.7 & .316 & 0.66 & $3.32 \times 10^{-7}$ & 1987 & 10087 & \\
\hline
\end{tabular}

a $\mathrm{W}=$ mass water content.

b $\theta=$ volumetric water content $=\mathrm{W}\left(\rho_{\mathrm{b}} / \rho_{\mathrm{w}}\right)$ where $\rho_{\mathrm{b}}$ is bulk density $\left(1.61 \mathrm{~g} / \mathrm{cm}^{3}\right)$ and $\rho_{\mathrm{w}}$ is water density.

b Acid extractable concentration minus water extractable concentration.

c Water extractable concentration scaled to water content.

${ }^{\mathrm{d}} \mathrm{R}_{\text {-app }}$ (apparent) $=1+\left(\rho_{\mathrm{b}} / \theta\right) \mathrm{K}_{\mathrm{d}}$ where $\theta$ is the volume fraction water and $\mathrm{K}_{\mathrm{d}}$ was calculated from the water and acid extraction data.

e $\mathrm{K}_{\mathrm{d}}=$ distribution coefficient $=$ sorbed concentration/aqueous concentration.

${ }^{\mathrm{f}} \mathrm{R}_{\text {-adj }}$ (adjusted) $=1+\left(\rho_{\mathrm{b}} / \theta\right) \mathrm{K}_{\mathrm{d}}$ where $\theta$ is the volume fraction water and $\mathrm{K}_{\mathrm{d}}$ was calculated from the water extraction data and total Cr analyses by XRF.

$\mathrm{g}$ Used in XANES analyses.

$\mathrm{HNO}_{3}$ extraction of the sediments (Fig. 3b) that demonstrated a sizable sorbed $\mathrm{Cr}$ pool that was retarded relative to the water extractable pool, with the maximum retardation effect noted at $25 \mathrm{~m}$ (Sample 7A). In contrast, sorbed ${ }^{99} \mathrm{Tc}$ was not observed (not shown). We operationally define sorbed $\mathrm{Cr}$ as that fraction of solid-associated $\mathrm{Cr}$ that is soluble in $8 \mathrm{~N} \mathrm{HNO}_{3}$, but not in water. The sorbed $\mathrm{Cr}$ may exist in a precipitated or strongly adsorbed state. Similar extents of $\mathrm{Cr}$ retardation were observed in two other boreholes placed in the SX tank farm (41-09-39, and SX-115; Serne et al., 2001b, 2001c). The vadose zone waste plume lies in a zone of residual high heat from tank waste boiling in the 1960s (Fig. 3c).

The $\mathrm{Cr}$ data for the sorbed and water-extractable pools in Figure 3 were referenced to sediment mass for clear comparison. It is noteworthy that the water contents of many of the samples were low, and the corresponding pore water concentrations of $\mathrm{Cr}$ were high in the two peak areas of the plume (24.8-30.1 m, 35.4-40.6 m), ranging between 0.1 and 0.365 $\mathrm{mol} / \mathrm{L}$ (Table 2). These porewater concentrations of $\mathrm{Cr}$, as well as those for $\mathrm{Na}^{+}$and $\mathrm{NO}_{3}^{-}$(Fig. 3a) were similar in magnitude to those estimated for tank 108 at the time of leakage (Table 1), indicating little mixing of waste waters with vadose zone porewaters or meteoric water in the core of the plume. In-situ distribution coefficients $\left(\mathrm{K}_{\mathrm{d}}\right)$ for $\mathrm{Cr}$ from the $\mathrm{SX}-108$ core samples (Table 2) were low within these plume regions (0.0075-0.0489) except for the $25 \mathrm{~m}$ sample (7A, 0.183). Because of their low volumetric water contents (Table 2), however, these $\mathrm{K}_{\mathrm{d}}$ 's propagated into apparent retardation factors $\left(\mathrm{R}_{\text {-app}}\right.$, Table 2$)$ that ranged between 1.2-3.96 for the plume regions. With the exception of Sample 7A, the average $\mathrm{R}_{\text {-app }}$ for the plume regions was $1.46 \pm 0.16$. The in-situ $\mathrm{K}_{\mathrm{d}}$ 's therefore imply a level of retardation, relative to $\mathrm{NaNO}_{3}\left(\mathrm{R}_{\text {-app }}\right.$ $\approx 1$ ), that is greater than displayed by the distribution profile in (Fig. 3). The sorbed $\mathrm{Cr}$ concentrations $(\mu \mathrm{mol} / \mathrm{g}$ ) and computed $\mathrm{K}_{\mathrm{d}} / \mathrm{R}_{\text {-app }}$ values in Table 2 defined two other regions in the borehole worthy of note: i.) sediments that had little or no contact with the waste solutions and whose sorbed $\mathrm{Cr}$ concentrations were representative of background (Samples 11A, 12A, 16A, 17A; average $\mathrm{Cr}$-sorbed $=0.55 \mu \mathrm{mol} / \mathrm{g}$ ), and ii.) a region of elevated, sorbed $\mathrm{Cr}$ near the tank apparently washed free of soluble $\mathrm{Cr}$ (and other soluble HLW) residuals by meteoric waters (Samples 3A, 4A, and 5A; note low concentrations of porewater $\mathrm{Na}^{+}$and $\mathrm{NO}_{3}^{-}$in these samples). These latter samples (3A-5A) contained extremely high levels of sorbed ${ }^{137} \mathrm{Cs}$ indicating the migration of HLW through them.

A variety of groundwater plumes containing $\mathrm{Cr}(\mathrm{VI})$ exist in the Columbia River corridor (the 100, or reactor areas) of the Hanford Site (Poston et al., 2001). The Cr(VI) in these plumes resulted from the discharge of $\mathrm{CrO}_{4}^{2-}$ (a corrosion inhibitor) in a dilute waste stream to the soil surface. There is little or no evidence for $\mathrm{Cr}(\mathrm{VI})$ retardation in either the oxic vadose zone or aquifer sediments associated with these particular plumes. The observed retardation of $\mathrm{Cr}$ beneath the leaked SX waste tanks was, therefore, anomalous, and the experiments described herein were performed to provide insights on the responsible attenuation mechanism.

\subsection{Chemical and Mineralogic Characteristics of the Contaminated Sediments}

Nine samples from two of the boreholes were analyzed for their total $\mathrm{Cr}$ content by X-ray fluorescence (XRF, Table 3). The depth locations of the analyzed sediments are noted in Figure 3. In general, the XRF data correlated well with that 
Table 3. Selected characteristics of studied core samples.

\begin{tabular}{|c|c|c|c|c|c|c|c|c|c|c|c|}
\hline \multirow[b]{2}{*}{ Sample } & \multirow{2}{*}{$\begin{array}{c}\text { Depth }^{\mathrm{a}} \\
(\mathrm{m} \text {-bags })^{\mathrm{g}}\end{array}$} & $\mathrm{Cr}_{\mathrm{XRF}}{ }^{\mathrm{b}}$ & \pm & $\mathrm{Cr}_{\mathrm{A}}^{\mathrm{c}}$ & $\mathrm{Cr}_{\mathrm{W}}{ }^{\mathrm{d}}$ & $\mathrm{Ba}_{\mathrm{A}}^{\mathrm{c}}$ & $\mathrm{Ba}_{\mathrm{W}}{ }^{\mathrm{d}}$ & $\mathrm{SO}_{4}^{2-}-\mathrm{S}_{\mathrm{A}}{ }^{\mathrm{c}}$ & $\mathrm{SO}_{4}^{2-}-\mathrm{S}_{\mathrm{W}}{ }^{\mathrm{d}}$ & \multirow[b]{2}{*}{$\mathrm{pH}$} & \multirow[b]{2}{*}{$\mathrm{AD}^{\mathrm{e}}$} \\
\hline & & \multicolumn{8}{|c|}{$\mu \mathrm{g} / \mathrm{g}$} & & \\
\hline \multicolumn{12}{|c|}{ SX-108 Borehole } \\
\hline $3 \mathrm{~A}$ & 20.8 & 225 & 14 & 125 & 0.81 & 74.6 & 0.03 & 210 & 7.87 & 9.58 & high \\
\hline $6 \mathrm{~A}$ & 24.8 & 955 & 49 & 641 & 443 & 92.5 & 0.008 & 229 & 4.86 & 8.00 & low \\
\hline $7 \mathrm{~A}$ & 26.1 & 1297 & 149 & 1230 & 305 & 97.1 & 0.17 & 471 & 214 & 9.55 & med \\
\hline $8 \mathrm{~A}$ & 27.4 & 2098 & 227 & 1460 & 761 & 77.4 & 0.012 & 417 & 207 & 7.83 & low \\
\hline $9 \mathrm{~A}$ & 28.8 & 1394 & 71 & 823 & 491 & 90.0 & 0.012 & 396 & 174 & 7.88 & low \\
\hline $13 \mathrm{~A}$ & 35.4 & 931 & 40 & 681 & 429 & 135 & 0.042 & 336 & 91.7 & 7.99 & low \\
\hline $14 \mathrm{~A}$ & 38.0 & 565 & 30 & 452 & 307 & 103 & 0.078 & 427 & 113 & 7.82 & low \\
\hline \multicolumn{12}{|l|}{$41-09-39$} \\
\hline $7 \mathrm{ABC}$ & 25.9 & 2090 & 53 & 1530 & 753 & 105 & 0.014 & - & 103 & 8.70 & $n d^{\mathrm{f}}$ \\
\hline $6 \mathrm{AB}$ & 28.2 & 1186 & 61 & 1280 & 714 & 92.4 & 0.060 & - & 80.7 & 8.33 & $n d^{f}$ \\
\hline
\end{tabular}

a Tank bottoms are at $16.5 \mathrm{~m}$ and groundwater is at approximately $45 \mathrm{~m}$.

b $\mathrm{Cr}$ values for 7A, 8A, 13A, 7ABC, and 6AB reported as the means and standard deviations of triplicate analyses. Values for 3A, 6A, 9A, and 14A are single XRF analyses where error was estimated from XRF standards. (Section 2.2)

c Determined by $8 \mathrm{~N} \mathrm{HNO}_{3}$ extraction. Units are $\mu \mathrm{g} / \mathrm{g}$ as $\mathrm{Cr}$, Ba or $\mathrm{S}$.

d Determined by 1:1 water extraction. Units are $\mu \mathrm{g} / \mathrm{g}$ as $\mathrm{Cr}$, Ba or $\mathrm{S}$.

e Alteration degree by SEM.

f Not determined.

g bgs $=$ below ground surface.

extracted from the sediments with acid $\left(8 \mathrm{~N} \mathrm{HNO}_{3}\right)$. On average, however, the XRF-determined $\mathrm{Cr}$ concentrations were higher. The difference between the XRF and acid extraction $\mathrm{Cr}$ concentrations may result from: i.) the incomplete acid solubilization of native $\mathrm{Cr}(25-50 \mu \mathrm{g} / \mathrm{g})$ present as a trace substitution in hornblende and other primary mineral phases, ii.) the variability of the non-homogenized samples used for acid extraction, and/or iii.) the presence of an unknown acid-inert or low solubility $\mathrm{Cr}$ phase in the contaminated sediments.

Hanford formation sediments in the $S$-SX tank farm are Pleistocene-age, catastrophic flood deposits of mixed geologic provenance. While sediment texture varies with depth through the $\mathrm{Cr}$ plume (from coarse to silty sand), XRD and optical microscopic analyses indicate that sediment mineral composition remains relatively constant from the upper to lower Hanford formation (McKinley et al., 2001a). There is a tendency for the chlorite to smectite ratio to increase with sediment age (depth), but this detail may be inconsequential to $\mathrm{Cr}$ geochemistry. The sand mineralogy is dominated by quartz, plagioclase, hornblende, and mica (muscovite, biotite) with minor magnetite, orthoclase, and ilmenite; and the silt and clay mineralogy contains micas, vermiculite, chlorite (clinochlore), and ferrigenous beidellite (Zachara et al., 2002).

XRD analyses of Cr-containing sediments from both the 41-09-39 and SX-108 boreholes did not show identifiable mineralogic changes resulting from contact with the REDOX waste supernatant that contained high concentrations of $\mathrm{OH}^{-}$and $\mathrm{Al}(\mathrm{OH})_{4}^{-}$(Table 1) (McKinley et al., 2001a). SEM micrographs, however, showed clear evidence for waste-induced dissolution and precipitation reactions (Fig. 4). Micas, in particular, were a useful reference phase because they were ubiquitous and showed no physical evidence of weathering in pristine Hanford sediments. Muscovite and biotite, whose surfaces were clean in deeper core sections (e.g., Sample 17A, Fig. $4 a)$, were highly encrusted with poorly crystalline sodiumaluminosilicates near the tank (Samples 3A and 7A). Sediment samples taken from near the tank (e.g., Sample 3A, Fig. 4b), showed high degrees of alteration. Generally, the degree of alteration noted by SEM decreased with depth and distance from the tank as a result of base neutralization by mineral dissolution and precipitation. The extent of mineral alteration qualitatively correlated with the measured $\mathrm{pH}$ of the $1: 1$ water extract of the sediment samples (Table 3 ). The natural $\mathrm{pH}$ of these sediments ranged between $\mathrm{pH}=7.5$ to 8.5 in the absence of caliche, which was found occasionally.

Samples containing the highest $\mathrm{Cr}$ concentrations from SX-108 (Samples 7A, 8A, and 9A) showed contrasting degrees of alteration. Sample 7A showed moderate secondary mineralization (Fig. 4c) and mica edge alteration, while Samples 8A and 9A were relatively pristine (not shown). The formation of secondary zeolites, observed by others in laboratory simulations of waste-sediment interactions (Bickmore et al., 2001; Nyman et al., 2000), was hypothesized for the most altered samples, 3A and 7A. Identification of zeolite phases on these sediments was difficult, however, because they were mineralogically heterogeneous and the apparent waste-induced secondary phases were small and intermixed with existing clasts, and were not distinguishable by morphology or size. The potential impact of co-disposed ${ }^{137} \mathrm{Cs}$ was used as an aid to finding zeolitic material. It was known that while the majority of waste ${ }^{137} \mathrm{Cs}$ was associated with micas in these sediments (McKinley et al., 2001b), zeolites were also capable of sorbing ${ }^{137}$ Cs (Akyuz, 1996; Liang and Tsai, 1995). Samples 3A and 7A were therefore screened using a sensitive autoradiography method (Zeissler et al., 1998) to identify radioactive clasts. These clasts were examined for surface-adhering secondary minerals compositionally consistent with zeolites. Quartz grains in particular (Fig. 5) were found to include $\mathrm{Na}-\mathrm{Al}-\mathrm{Si}-\mathrm{O}$ precipitate phases on their surfaces; these precipitates were hypothesized to be wasteinduced zeolites, because the unaltered sediments did not contain such material, particularly as a surface-adherent phase. 
a. SX-108 17A

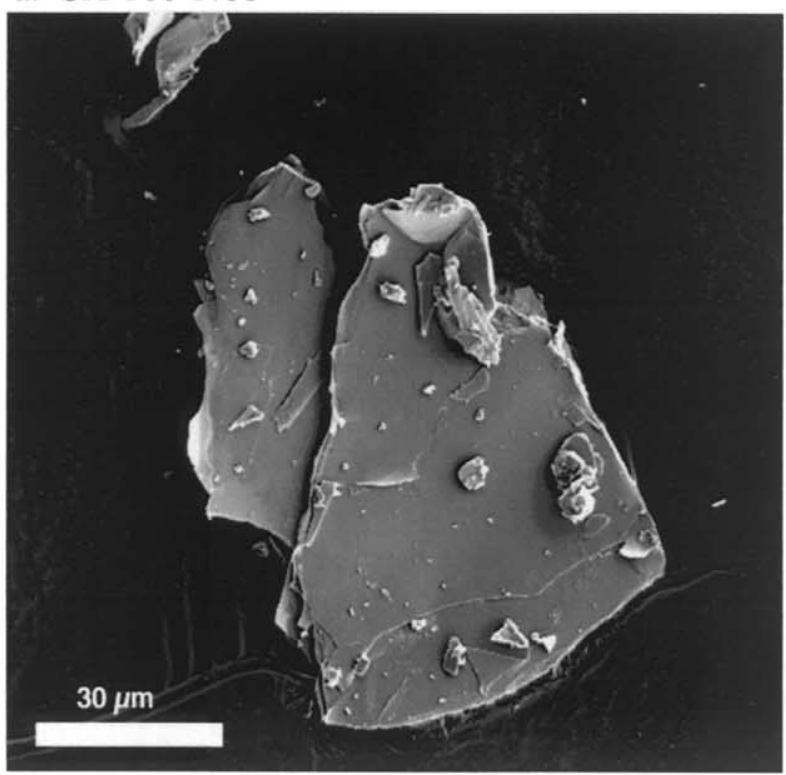

b. SX-108 3A

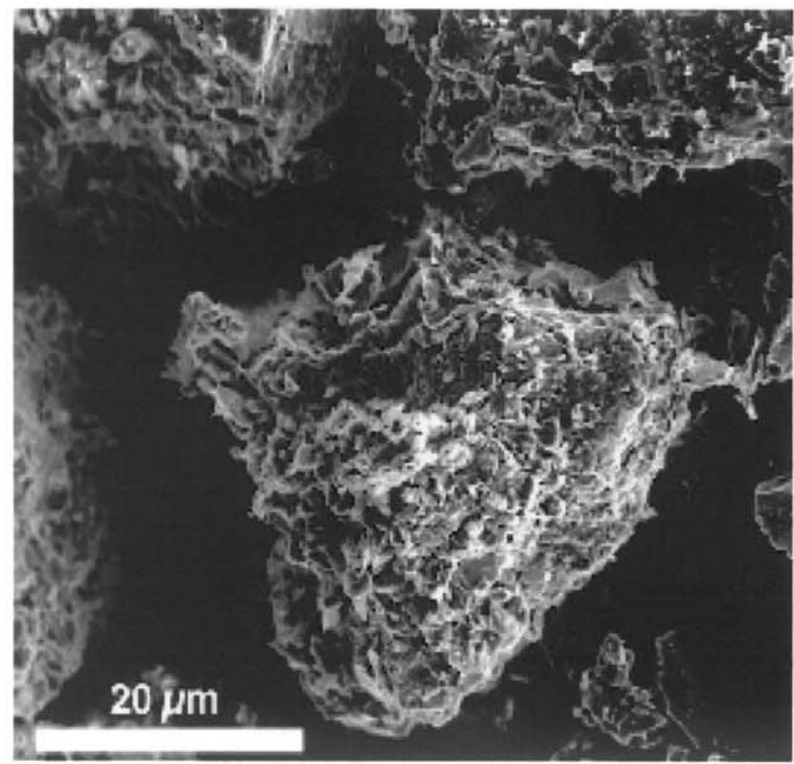

\section{c. SX-1087A}

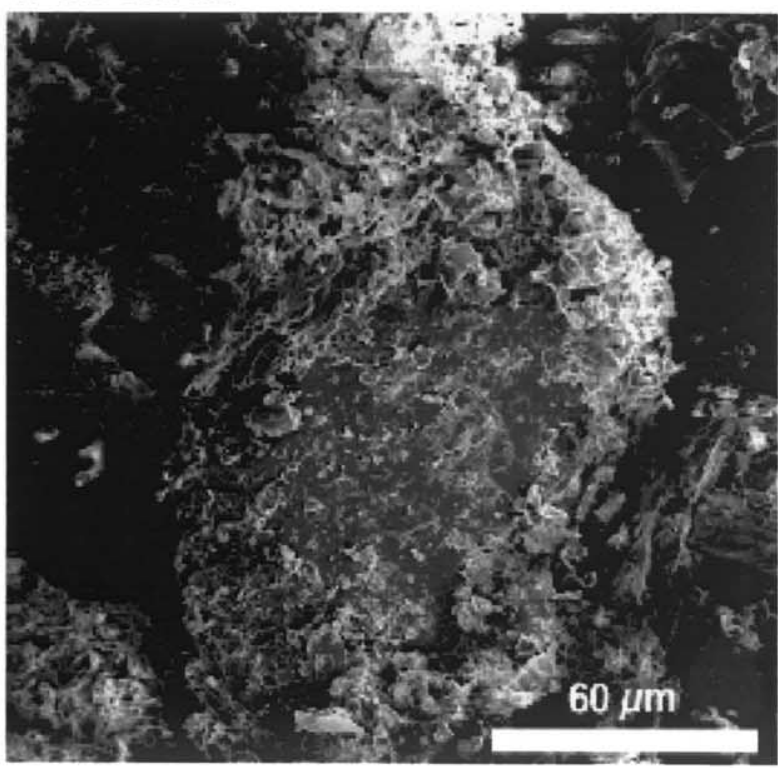

Fig. 4. Scanning electron micrographs of mica particles from SX-108 borehole sediments. a.) Sample 17A (45.4 m), b.) Sample 3A $(20.8 \mathrm{~m})$, and c.) Sample 7A $(26.1 \mathrm{~m})$. Note scale bars. The mica grains range from 20 to $50 \mu \mathrm{m}$.

\subsection{Xanes Analyses}

Eight $\mathrm{Cr}$ containing sediment samples from Table 3 were analyzed by X-ray absorption near edge structure (XANES) spectroscopy at SSRL to determine the valence distribution of $\mathrm{Cr}(\mathrm{III} / \mathrm{VI}$ ) (Fig. 6). Sample 3A had insufficient total $\mathrm{Cr}$ for XANES analysis. The percent $\mathrm{Cr}(\mathrm{VI})$ was calculated from the sample specific pre-edge peak height and positions using the following beamline-specific calibration curves (Fig. 7):

$$
\text { BL 11-2: \% Cr(VI) }=102.83 \text { (height) }-12.80
$$

$$
\text { BL 4-3: \%Cr(VI) = 128.64(height })-12.77
$$

The calibration curve correctly predicted the $\mathrm{Cr}(\mathrm{VI})$ percentages of three blind samples that were used to test the calibration process.

The normalized Cr K-XANES spectra of the eight Hanford borehole samples all displayed the presence of both $\mathrm{Cr}(\mathrm{VI})$ and Cr(III) (Fig. 6, Table 4). The largest Cr(III) concentration [smallest Cr(VI)] was observed in SX-108 Sample 7A, which had the highest $\mathrm{pH}$, the largest extent of mineral alteration of the samples analyzed by XANES, and largest $\mathrm{K}_{\mathrm{d}}$. The highest $\mathrm{Cr}(\mathrm{VI})$ concentrations were noted deep in the SX-108 core 
Sample SX-108 3A


Fig. 5. Zeolite-like surface precipitates on a radioactive quartz grain isolated from Sample 7A observed by scanning electron microscopy. Quartz grains from deeper in the profile were clean of such material.

where $\mathrm{pH}$ was near ambient and where mineral alteration was minimal. These data indicate that $\mathrm{Cr}(\mathrm{VI})$ present initially in the REDOX waste was variably reduced by the Hanford sediments.

\subsection{Chromium Leaching Behavior}

The leaching of $\mathrm{Cr}$ from all the contaminated sediments was characterized by a rapid advective removal of $\mathrm{CrO}_{4}^{2-}$ in the initial 5 pore volumes, followed by a slow, sustained release of $\mathrm{CrO}_{4}^{2-}$ for extended pore volumes (Fig. 8) at concentrations ranging from 2 to $10 \mathrm{mg} / \mathrm{L}$. The initial, high concentration pulse contained the bulk of the soluble $\mathrm{CrO}_{4}^{-}$(48 to $>100 \%$ ) that was removed from the sediments during the column study (Table 5). Not all of the Cr(VI) pool determined by XANES analysis was leachable from the sediments (Table 5); the only exception was 41-09-039 Sample 7ABC (to be discussed below). The leachable fraction ranged from $57-100 \%$ (41-09-39 7ABC) and, in the SX-108 cores, Cr(VI) leachability appeared to increase with depth and distance away from the source. The Hanford sediments exhibit little or no adsorptive retardation for $\mathrm{Cr}(\mathrm{VI})$ in their natural state (Poston et al., 2001). Recent transport studies with uncontaminated S-SX tank farm sediments found no retardation of $\mathrm{Cr}(\mathrm{VI})$ (data to be published). Based on these data, the $\mathrm{Cr}(\mathrm{VI})$ leaching profile of sediment $7 \mathrm{ABC}$ (Fig. 9) was expected. Yet, it was the only sediment to release all of its $\mathrm{Cr}(\mathrm{VI})$ pool (Table 5).

The leaching behavior of one of the sediments (9A) was studied in triplicate to determine the leaching variance. This experiment indicated a variance of $10-12 \%$ for the leachable $\mathrm{Cr}$ (VI) concentration. This uncertainty was considered good given the high radioactivity of the samples and the difficulties associated with packing such materials into small columns. The observance of leachable $\mathrm{Cr}(\mathrm{VI})$ in excess of $100 \%$ for one sediment (41-09-39, 7ABC), however, indicated that subsamples of this material used for total $\mathrm{Cr}$ analyses and the column study were inhomogeneous and contained different total $\mathrm{Cr}$ concentrations. The 41-09-39 materials were in general, more aggregated than those from SX-108 and were more difficult to homogenize given their physical state and radioactivity.

The 7ABC column data were modeled with an advectiondispersion model to evaluate the leaching behavior that should occur if all the $\mathrm{CrO}_{4}^{2-}$ determined by XRF/XANES was present in pore space, and was freely soluble and unretarded. A single dispersion coefficient was fit to the leaching data of Sample $7 \mathrm{ABC}$ (Fig. 9). The leaching behavior of 7ABC was unique compared to the others in that all of the $\mathrm{CrO}_{4}^{2-}$ was leached in the first five pore volumes. Hence, $\mathrm{CrO}_{4}^{2-}$ release over the entire column experiment could be fit to a nonreactive transport model by simply optimizing dispersivity. A fitted dispersivity of $1.2 \mathrm{~cm}$ yielded an excellent fit to the leaching data for sediment 7ABC (solid line, Fig. 9).

The dispersivity $(\alpha=1.2 \mathrm{~cm})$ was large for the size of columns used. Based on the mean sediment particle size and flow velocity, the calculated dispersivity would be $0.052 \mathrm{~cm}$, a factor of 25 less than the fitted value. The high dispersivity resulted from two primary factors. First, the high radioactivity of the samples necessitated rapid column packing with clumsy protective gear to minimize dose to and contamination of laboratory personnel. These less than optimal experimental conditions may have lead to physical heterogeneities in the sediment columns that encouraged preferential flow. Second, small columns were used to lessen dose during experimental setup and performance. The column size may have been too small, compared to mean particle or aggregate size, to mitigate column boundary effects. The large dispersivity does not compromise the results, but it need be given appropriate consideration in the interpretation of the $\mathrm{Cr}(\mathrm{VI})$ leaching profile and the stop-flow event.

The leaching data for the other sediments were simulated as if the $\mathrm{CrO}_{4}^{2-}$ content as determined by XANES analysis was 


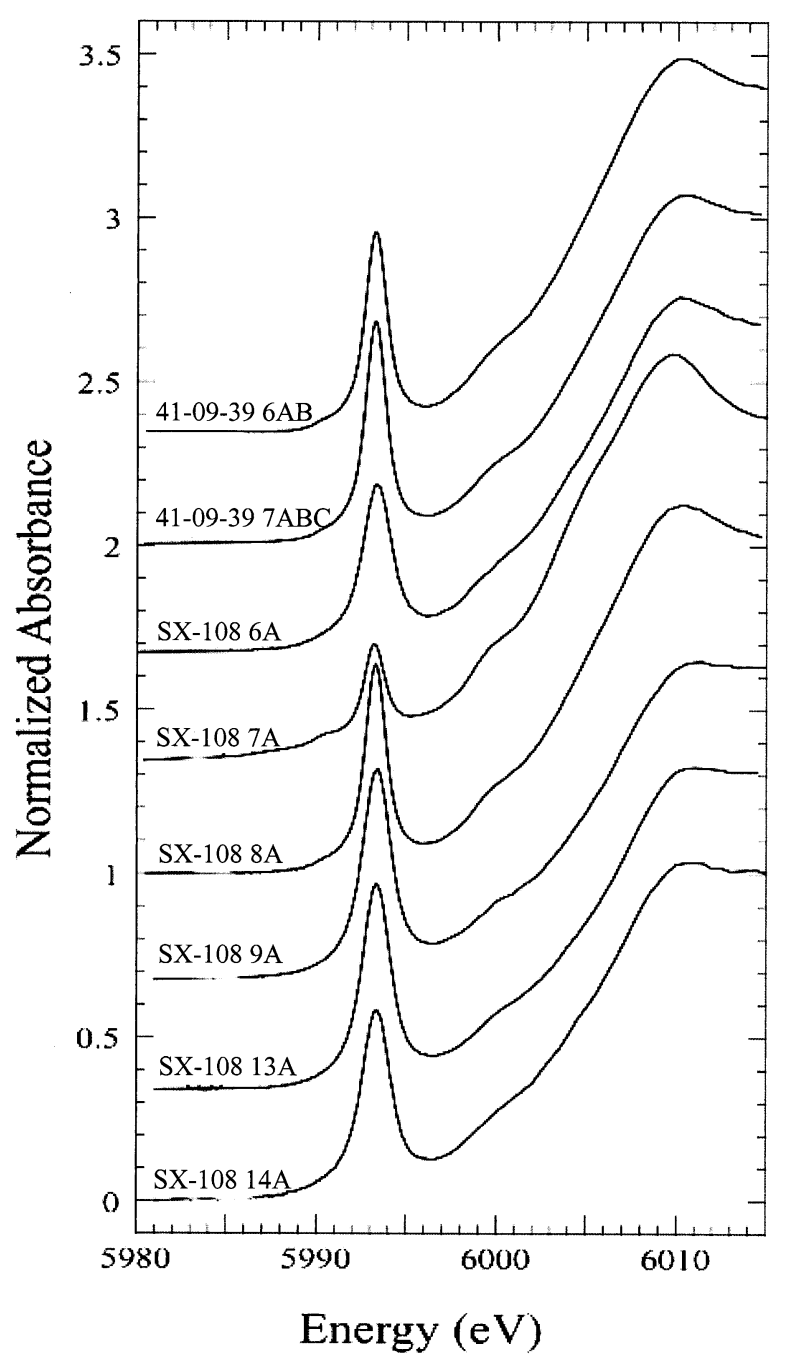

Fig. 6. Normalized Cr K-edge XANES spectra of S-SX sediment samples.

nonreactive and unretarded. Assuming a dispersivity of $1.2 \mathrm{~cm}$, breakthrough curves were calculated using the following relationship:

$$
D_{L}=D_{0}+\alpha v^{N}
$$

where $D_{L}$ is the longitudinal hydrodynamic dispersion, $D_{0}$ is the molecular diffusion, $\alpha$ is the dispersivity, $\mathrm{v}$ is the velocity, and $\mathrm{N}$ is an empirical parameter between 1.0 and 1.5 (for these simulations $\mathrm{N}$ was assumed to be 1.0; Rose, 1977). Unlike sediment $7 \mathrm{ABC}$, no other sediment exhibited complete release of its $\mathrm{CrO}_{4}^{2-}$ content during the initial phase of leaching. The modeling results for the other sediments (solid lines in Fig. 8) indicated that while there was an initial washout event, a significant fraction of the $\mathrm{Cr}(\mathrm{VI})(15-43 \%)$ was in a form (e.g., precipitated, adsorbed, occluded) that was retarded and resistant to leaching (Table 5). The leaching resistant fraction of $\mathrm{Cr}$ (VI) increased with: i.) proximity to the HLW source, and ii.) the degree of mineral alteration as observed by SEM. Attempts to use dispersivity as a fitting parameter for the initial washout event did not significantly improve the fits, even when the dispersivity was allowed to vary over several orders of magnitude. We concluded, therefore, that there were physiochemical differences in the speciation or intraparticle distribution of $\mathrm{Cr}(\mathrm{VI})$ between the various sediment samples.

Each of the columns received a $19 \mathrm{~h}$ stop-flow period after leaching with at least 15 pore volumes of $0.5 \mathrm{~mol} / \mathrm{L} \mathrm{NaNO}_{3(\mathrm{aq})}$ (Fig. 10). In all the sediments studied (except 7ABC), the $\mathrm{Cr}(\mathrm{VI})$ concentration in the entrained porewater increased during the stop-flow period. The quantity of $\mathrm{Cr}(\mathrm{VI})$ resupply represented from $4.8-19 \%$ of the residual $\mathrm{Cr}(\mathrm{VI})$ left at the initiation of the stop-flow event (Table 6). No apparent correlation was observed between the total $\mathrm{Cr}(\mathrm{VI})$ concentration released during stop-flow and the sample depth or extent of mineral alteration. The stop-flow data indicated that the "leaching-resistant" fraction of $\mathrm{Cr}(\mathrm{VI})$ was in contact with the aqueous phase, and its apparent solubility was rate-limited by mass transfer (e.g., intraparticle diffusion) or chemical kinetics (e.g., dissolution or desorption rate). Mass transfer effects could be exacerbated if column physical heterogeneities created preferential flow and hydraulically inactive regions. Unfortunately, the relative importance of these physical and chemical constraints could not be discriminated by the current data.

\section{DISCUSSION}

Our results indicate that a portion of the Cr(VI) present in the leaked HLW supernatant was reduced while migrating through the oxidized Hanford sediments. This conclusion is based on the assumption that all $\mathrm{Cr}$ present in the REDOX waste supernatant at the time of leakage was $\mathrm{Cr}(\mathrm{VI})$ and not a mixture of $\mathrm{Cr}(\mathrm{VI})$ and $\mathrm{Cr}(\mathrm{III})$ species. While it is now known that $\mathrm{Cr}$ exists in Hanford tank waste sludge as Cr(III) (Lumetta and Rapko, 1999; Lumetta et al., 1998), speciation measurements were not performed on REDOX waste supernatant at times and under conditions relevant to this leak event. Given that $\mathrm{Cr}(\mathrm{III})$ undoubtedly existed in the REDOX tank sludge at the time of leakage, is it possible that $\mathrm{Cr}$ (III) species may have existed in the highly alkaline, hot, REDOX waste brine? Could the transport of such species explain the noted subsurface distribution of $\mathrm{Cr}$ and its valence state distribution? These and other questions are addressed below.

\subsection{Source Term Chemistry}

$\mathrm{Cr}(\mathrm{III})$ precipitates rapidly at circumneutral $\mathrm{pH}$ and above as fine-grained $\mathrm{Cr}(\mathrm{OH})_{3}$. This solid phase maintains relatively low $\mathrm{Cr}$ (III) solubility at circumneutral $\mathrm{pH}$, but is amphoteric (Rai et al., 1987). $\mathrm{Cr}(\mathrm{OH})_{3}$ solubility increases at alkaline $\mathrm{pH}$ through formation of $\mathrm{Cr}(\mathrm{OH})_{4}^{-}$(aq). The solubility of $\mathrm{Cr}(\mathrm{OH})_{3}$ is relatively constant (at approximately $10^{-4.5} \mathrm{~mol} / \mathrm{L}$ ) over the $\mathrm{OH}^{-}$ concentration range of $10^{-2}$ to $1 \mathrm{~mol} / \mathrm{L}$, but increases by as much as three orders of magnitude (up to $10^{-1} \mathrm{~mol} / \mathrm{L}$ ) as $\left[\mathrm{OH}^{-}\right]$is increased from 1 to $10 \mathrm{~mol} / \mathrm{L}$ (Rai et al., 2001). This marked solubility increase may result from $\mathrm{Cr}(\mathrm{III})$ oligomerization. The REDOX waste was sufficiently alkaline (Table 1) to induce solubility enhancements of $\mathrm{Cr}(\mathrm{OH})_{3(\mathrm{am})}$ to $10^{-1.75}$ $\mathrm{mol} / \mathrm{L}$, if indeed it was present and controlling $\mathrm{Cr}(\mathrm{III})$ solubility. This $\mathrm{Cr}$ concentration is close to that estimated for $\mathrm{Cr}(\mathrm{VI})$ in tank 108 supernatant (Table 1). 
a.
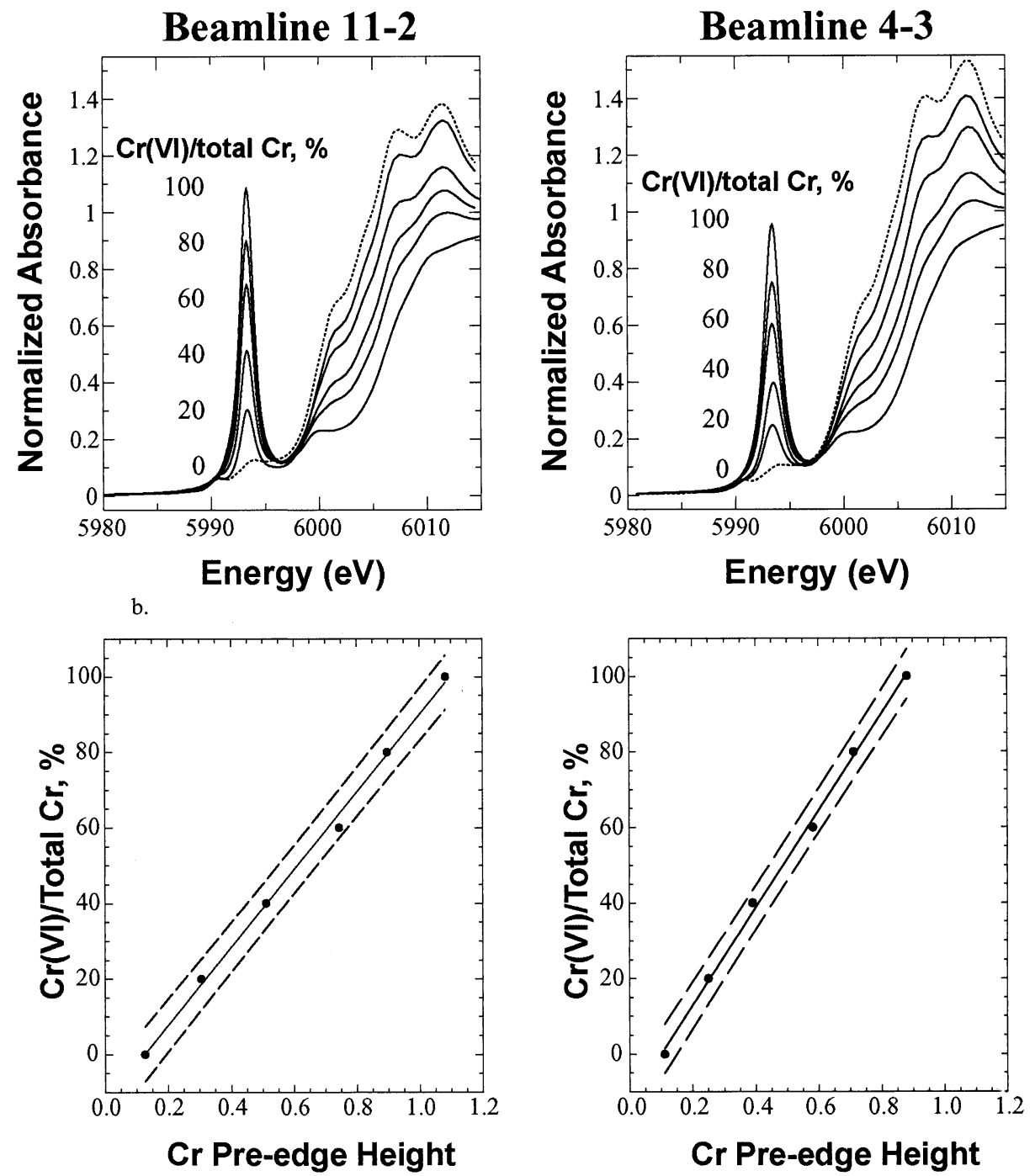

Fig. 7. Calibration curves for the determination of $\mathrm{Cr}(\mathrm{VI}) / \mathrm{Total} \mathrm{Cr}$ in a sample from the intensity of its XANES preedge feature for both beamlines used in study. a.) Preedge intensity for a set of standards with noted fractional contents of $\mathrm{Cr}(\mathrm{VI})$. b.) Resulting calibration curves used to determine $\mathrm{Cr}(\mathrm{VI})$ mole \% in Hanford samples.

Others, however, have found that elevated temperature counteracts the solubility enhancing effect of alkali on $\mathrm{Cr}(\mathrm{OH})_{3(\mathrm{am})}$ solubility by inducing rapid recrystallization to insoluble guyanaite [syn-(CrOOH); Lumetta et al., 1998], eskolaite $\left(\mathrm{Cr}_{2} \mathrm{O}_{4}\right.$; Swayambunathan et al., 1989) or other highly crystalline phases. The REDOX wastes in question were self-boiling from radioactive decay, and were stored at elevated temperatures for years before the leak event. The tendency for conversion of fine-grained to crystalline phases in these alkaline, high-temperature wastes is evidenced by the common presence of gibbsite $\left[\mathrm{Al}(\mathrm{OH})_{3}\right]$, diaspore $[\mathrm{Al}(\mathrm{O}) \mathrm{OH}]$, and boehmite $(\mathrm{AlOOH})$ in the tank waste sludge (Lumetta et al., 1998). Chromium(III)- containing phases have been identified directly in Hanford tank sludges and include grimaldite $[\mathrm{Cr}(\mathrm{O}) \mathrm{OH}]$, donathite $\left[\mathrm{Fe}(\mathrm{Cr}, \mathrm{Fe})_{2} \mathrm{O}_{4}\right], \mathrm{FeCr}_{2} \mathrm{O}_{4}, \mathrm{Mn}_{2} \mathrm{CrO}_{4}$, and others ( $\mathrm{Lu}-$ metta et al., 1998). Caustic leaching of $\mathrm{Cr}$-containing Hanford
Table 4. Results of Cr(VI) determination from XANES "pre-edge" heights.

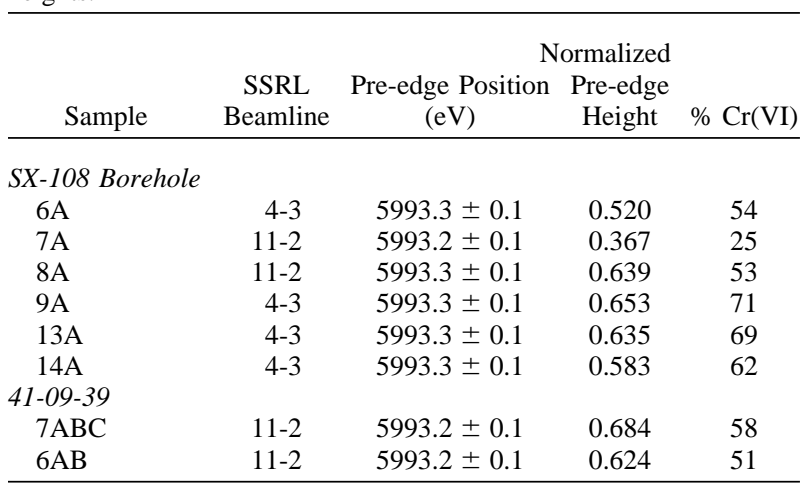




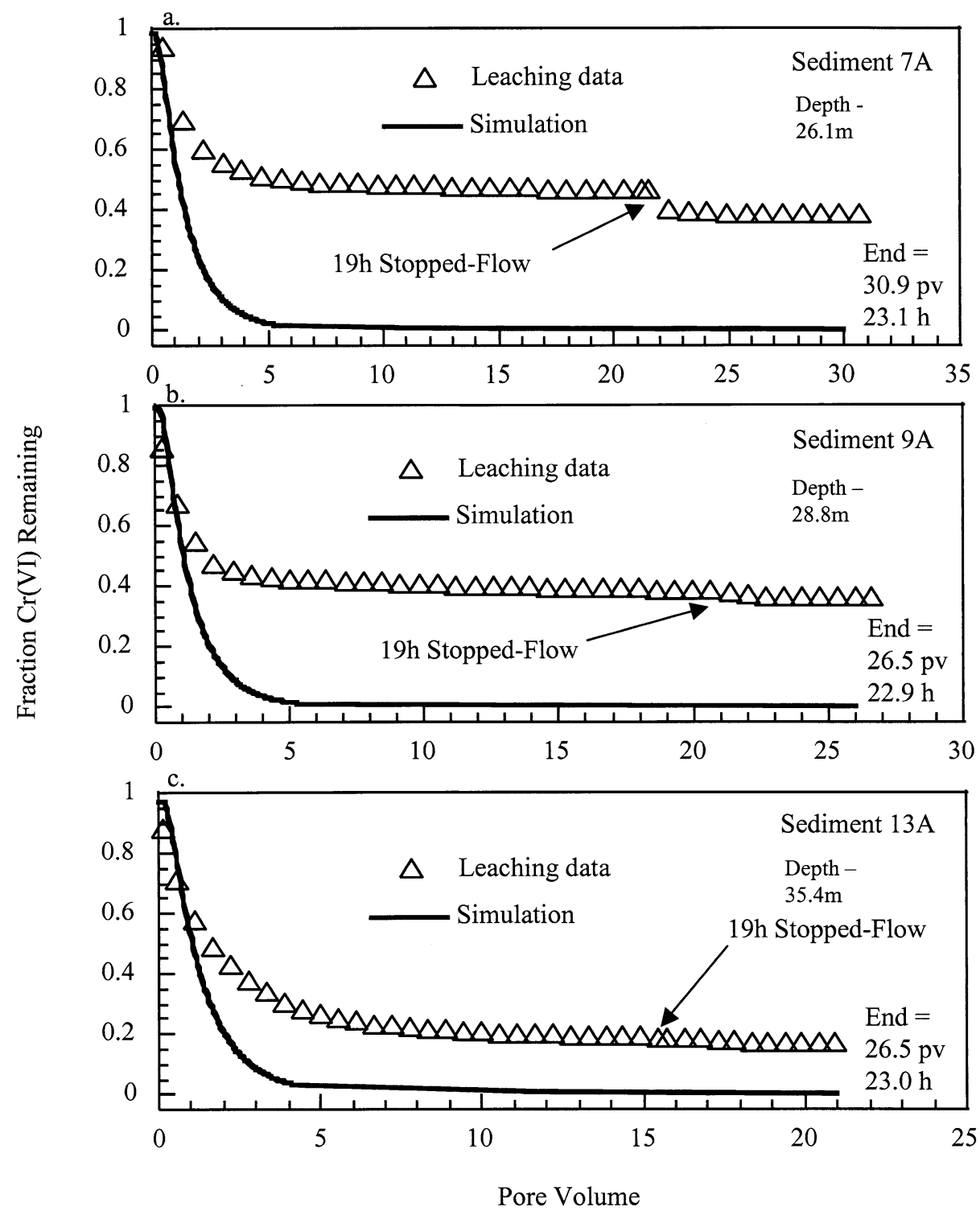

Fig. 8. Release of $\mathrm{Cr}$ from small columns leached with $0.5 \mathrm{~mol} / \mathrm{L} \mathrm{NaNO}_{3}$. Symbols are the data, solid curves are simulations of an advective-dispersion model without any retardation for $\mathrm{Cr}(\mathrm{VI})$. All other samples studied except 7ABC showed similar behavior. The column residence time was approximately $6 \mathrm{~min} /$ pore volume. The total elapsed time for the experiment was $21-22 \mathrm{~h}$ including the $19 \mathrm{~h}$ stop-flow event.

tank waste sludge generally produces little soluble Cr(III) (Lumetta and Rapko, 1999; Lumetta et al., 1998), an observation consistent with the presence of highly insoluble crystalline phases. These recent measurements suggest that little dissolved $\mathrm{Cr}(\mathrm{III})$ was present in the REDOX tank waste supernatant at the time of leakage. While movement of colloidal $\mathrm{Cr}$ (III) cannot be ruled out, it is difficult to envision that such a transport mechanism would produce the $\mathrm{Cr}(\mathrm{III}) /$ $\mathrm{Cr}(\mathrm{VI})$ ratios observed in Table 5. Rather, it is more probable that the distribution of Cr oxidation states in the S-SX sediment samples resulted from in-situ reduction of $\mathrm{Cr}(\mathrm{VI})$ to $\mathrm{Cr}(\mathrm{III})$ by sediment $\mathrm{Fe}$.

\subsection{A Potential Reduction Mechanism}

It is well known that $\mathrm{Fe}(\mathrm{II})$ in various forms is reactive with $\mathrm{CrO}_{4}^{2-}$, inducing reduction to an insoluble $(\mathrm{Cr}, \mathrm{Fe})(\mathrm{OH})_{3(\mathrm{~s})}$ precipitate that limits the concentration of $\mathrm{Cr}(\mathrm{III})_{(\mathrm{aq})}$ to less than $10^{-6} \mathrm{~mol} / \mathrm{L}$ between $\mathrm{pH} 4$ and 12 . The reaction is thermodynamically favored and kinetically viable over a range in $\mathrm{pH}$, temperature, and other geochemical variables. The homogeneous reduction reaction has been relatively well studied, and rate dependencies on $\mathrm{pH}$, temperature, and reactant concentrations established (Eary and Rai, 1988; Fendorf, 2000; Pettine et al., 1998; Sedlak and Chan, 1997). Adsorption of Fe(II) on 
Table 5. Cr(VI) release from contaminated sediments in packed columns by $0.5 \mathrm{M} \mathrm{NaNO}_{3}$.

\begin{tabular}{|c|c|c|c|c|c|c|c|c|}
\hline \multirow[b]{3}{*}{ Sample } & \multicolumn{3}{|c|}{$\mathrm{Cr}$ in Sediment } & \multicolumn{2}{|c|}{$\begin{array}{l}\mathrm{Cr}(\mathrm{VI}) \text { Leached from } \\
\text { Column Experiments }\end{array}$} & \multicolumn{2}{|c|}{ Cr(VI) Leached ${ }^{\mathrm{c}}$} & \multirow{3}{*}{$\begin{array}{c}\text { Sorbed/Precipitated } \\
\text { Cr Fraction }{ }^{\mathrm{g}}\end{array}$} \\
\hline & Total & $\mathrm{Cr}(\mathrm{VI})^{\mathrm{a}}$ & $\mathrm{Cr}(\mathrm{III})^{\mathrm{b}}$ & Initial $^{\mathrm{c}}$ & Total & Initial $^{\mathrm{c}}$ & Total & \\
\hline & \multicolumn{5}{|c|}{$\mu \mathrm{g} / \mathrm{g}$} & \multicolumn{2}{|c|}{$\%$} & \\
\hline \multicolumn{9}{|c|}{ SX-108 Borehole } \\
\hline $7 \mathrm{~A}$ & $1297 \pm 149$ & 324 & 973 & 156 & 206 & 48 & 64 & 0.84 \\
\hline $8 \mathrm{~A}$ & $2098 \pm 227$ & 1112 & 986 & 537 & 629 & 48 & 57 & 0.70 \\
\hline $9 A^{d}$ & 1394 & 990 & 405 & $498 \pm 56$ & $562 \pm 59$ & 50 & 57 & 0.59 \\
\hline $13 \mathrm{~A}$ & $931 \pm 40$ & 642 & 289 & 444 & 545 & 69 & 85 & 0.41 \\
\hline $14 \mathrm{~A}$ & 565 & 350 & 215 & 253 & 274 & 72 & 78 & 0.52 \\
\hline \multicolumn{9}{|l|}{$41-09-39$} \\
\hline $7 \mathrm{ABC}$ & $2090 \pm 53$ & 1212 & 878 & 1374 & 1542 & $113^{\mathrm{f}}$ & $127^{\mathrm{f}}$ & N/A \\
\hline $6 \mathrm{AB}$ & $1186 \pm 61$ & 605 & 582 & 405 & 480 & 67 & 79 & 0.60 \\
\hline
\end{tabular}

a Based on total $\mathrm{Cr}(\mathrm{VI})$ in sediment as determined by XANES.

b By difference [Total (XRF) - Cr(VI)(XANES)].

c Initial portion of leached $\mathrm{Cr}(\mathrm{VI})$ is arbitrarily taken as the first four pour volumes; the sum of $\mathrm{Cr}(\mathrm{VI})$ released after 30 to 35 pore volumes represents Total $\mathrm{Cr}(\mathrm{VI})$.

${ }^{d}$ Leached values are the result of 3 replicates.

e Percent of $\mathrm{Cr}(\mathrm{VI})$ determined by XRF/XANES.

${ }^{f}$ Values in excess of $100 \%$ are the result of sample inhomogeneity.

g $\underline{\mathrm{Cr}(\mathrm{III})+\text { nonleachable } \mathrm{Cr}(\mathrm{VI})}$

Fe(III) oxides, montmorillonite, kaolinite, and silica can accelerate the reduction rate (Buerge and Hug, 1999). Fe(II) that dissolves from $\mathrm{Fe}(\mathrm{II})$ containing mineral phases (e.g., hematite, where ferrous iron is a minor contaminant, and biotite) is reactive through a combined homogeneous and heterogeneous process (Eary and Rai, 1989; Eary and Rai, 1991). Fe(II)containing mineral phases present in Hanford sediment including biotite, chlorite, magnetite, and ilmenite have also been shown to reduce $\mathrm{Cr}(\mathrm{VI})$ through coordinative interfacial electron transfer reactions under select geochemical conditions.

Published information does not immediately confirm that Hanford Fe(II)-containing mineral phases should or even could be reactive toward chromate under the predominantly alkaline conditions of this study. For example, most studies of $\mathrm{CrO}_{4}^{2-}$ reaction with relevant mineral phases have been performed at pH 7 and below, with studies under acidic conditions being most common [biotite - (Ilton and Veblen, 1994; Ilton et al., 1997); magnetite and ilmenite - (White and Peterson, 1996); magnetite - (Peterson et al., 1996; Peterson et al., 1997a); chlorite and montmorillonite - (Brigatti et al., 2000a)]. Also, most of the above mono-mineralogic studies have been performed with unweathered mineral specimens with relatively clean mineral surfaces. In-situ weathering and reaction with oxidants such as $\mathrm{CrO}_{4}^{2-}$ and $\mathrm{O}_{2}$ may passivate the surface of magnetite, biotite, and other like phases, eliminating the possibility of direct coordinative electron transfer at the mineral

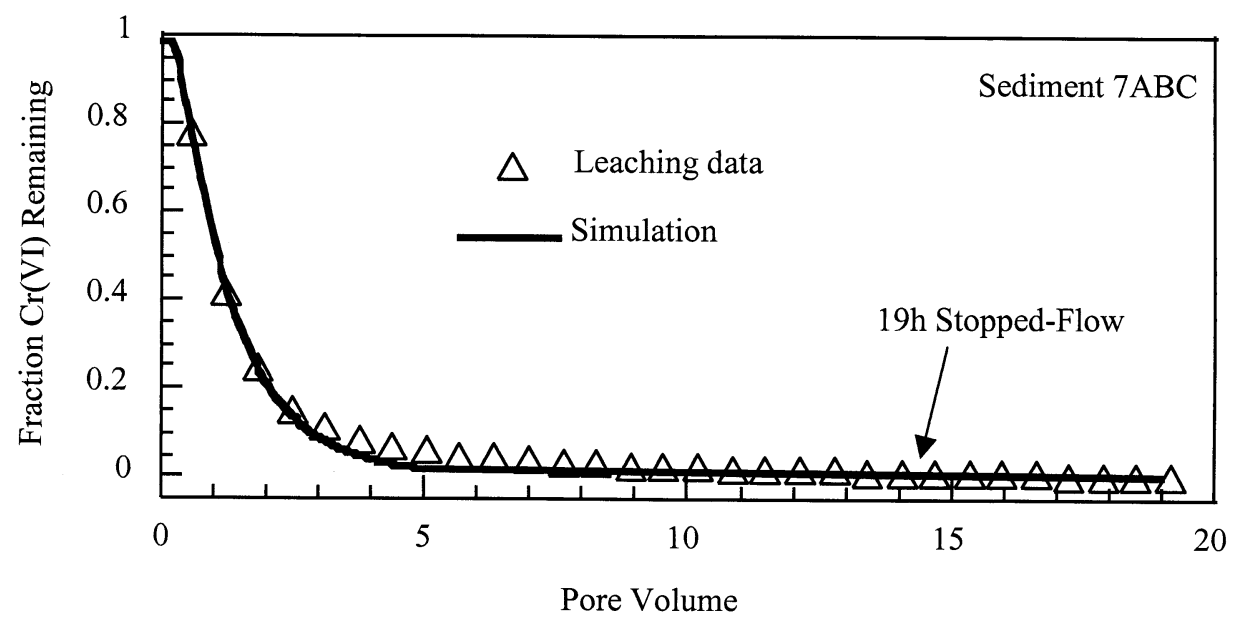

Fig. 9. Column leaching data and advection-dispersion model simulation for Sample 7ABC. This sample showed almost complete washout (e.g., no retardation) of the entire XANES-measured Cr(VI) pool in the first five pore volumes. A dispersion coefficient was fitted to this data that was used in the simulations of the column data from the other samples (e.g., Fig. 8) that showed $\mathrm{Cr}(\mathrm{VI})$ retardation. 



Fig. 10. Resupply of $\mathrm{Cr}$ during the $19 \mathrm{~h}$ stop-flow event. Note that aqueous $\mathrm{Cr}$ concentrations remain well above regulatory standard even after the extended leaching of 16 to over 20 pore volumes. The stop-flow event for Samples 7A and 9A was initiated after $2.1 \mathrm{~h}$ of electrolyte leaching, while that for 13A occurred after $1.6 \mathrm{~h}$.

surface (Peterson et al., 1997b; White and Peterson, 1996; White and Yee, 1985). Biotites extracted from the Hanford sediments exhibit a distinct weathering aureole under optical microscopy implying in-situ oxidation of structural $\mathrm{Fe}(\mathrm{II})$ around their perimeter (Zachara et al., 2002), and depletion of readily available $\mathrm{Fe}(\mathrm{II})$.

We suspect that base-catalyzed dissolution of Fe(II)-containing minerals in the Hanford sediment by the high concentrations of $\mathrm{OH}^{-}$present in the REDOX waste with concomitant release and reaction of $\mathrm{Fe}(\mathrm{II})$ with $\mathrm{CrO}_{4}^{2-}$ was the overall mechanism responsible for $\mathrm{Cr}(\mathrm{VI})$ reduction (Fig. 11). Evidence from the SX-108 core including the sediment $\mathrm{pH}$ values
Table 6. Water leachable $\mathrm{Cr}(\mathrm{VI})$ and resupply through stop-flow (S-F)

\begin{tabular}{|c|c|c|c|c|}
\hline \multirow[b]{2}{*}{ Sample } & \multirow[t]{2}{*}{$\begin{array}{c}\text { Total } \\
\mathrm{Cr}(\mathrm{VI})^{\mathrm{a}} \\
\end{array}$} & \multirow{2}{*}{$\begin{array}{c}\mathrm{Cr}(\mathrm{VI}) \text { Left Prior } \\
\text { to S-F Event }^{\mathrm{b}} \\
\mu \mathrm{g} / \mathrm{g} \\
\end{array}$} & \multicolumn{2}{|c|}{$\begin{array}{c}\text { Cr(VI) Leached after } \\
\text { S-F Event }{ }^{\mathrm{c}}\end{array}$} \\
\hline & & & & $\%$ \\
\hline \multicolumn{5}{|c|}{ SX-108 Borehole } \\
\hline $7 \mathrm{~A}$ & 324 & 145.5 & $26.2^{\mathrm{c}}$ & $18.0^{\mathrm{d}}$ \\
\hline $8 \mathrm{~A}$ & 1112 & 503.6 & 18.7 & 3.7 \\
\hline $9 \mathrm{~A}$ & 989 & $452.2 \pm 60.1$ & $21.7 \pm 0.6$ & $4.8 \pm 0.8$ \\
\hline $13 \mathrm{~A}$ & 642 & 121.0 & 8.1 & 6.7 \\
\hline $14 \mathrm{~A}$ & 350 & 73.8 & 9.6 & 12.9 \\
\hline \multicolumn{5}{|l|}{ 41-09-39 } \\
\hline $7 \mathrm{ABC}$ & 1212 & - & 41.1 & - \\
\hline $6 \mathrm{AB}$ & 604 & 145.6 & 27.7 & 19.0 \\
\hline
\end{tabular}

a Total $\mathrm{Cr}(\mathrm{VI})$ is estimated from total $\mathrm{Cr}$ XRF determination and \% Cr(VI) estimated by XANES.

b Difference between total $\mathrm{Cr}(\mathrm{VI})$ and cumulative amount of $\mathrm{Cr}(\mathrm{VI})$ removed prior toinitiation of stopped flow event; stopped flow event occurred after approximately 15 to 20 pore volumes.

c The cumulative $\mathrm{Cr}(\mathrm{VI})$ leached for the initial 5 pore volumes after flow was restarted.

d \% of residual $\mathrm{Cr}(\mathrm{VI})$ at beginning of S-F that was leached during the S-F event.

(Table 3) and SEM micrographs (Fig. 4) indicate that $\mathrm{OH}^{-}$ present in the HLW waste supernatant was neutralized through water-rock reaction. Unpublished data by our laboratories show increased reddening of SX tank farm sediment contacted with $1 \mathrm{~mol} / \mathrm{L} \mathrm{NaOH}$ under oxic conditions resulting from mineral $\mathrm{Fe}$ (II) dissolution, oxidation, and $\mathrm{Fe}(\mathrm{III})$ oxide precipitation.

Although data on mineral dissolution rates under basic conditions are limited, Knauss and Wolery (1989), Malmstrom and Banwart (1997), and Nagy (1995) show that the dissolution rates of both biotite and muscovite increase markedly above $\mathrm{pH}$ 7. At $\mathrm{pH} 10-12$, the dissolution rates of these micas approximate the high rates observed under acidic conditions. By analogy, soluble, finely divided phyllosilicates such as chlorite/ clinochlore and ferrigenous beidellite in the silt and clay sized fraction of the Hanford sediments are expected to react with $\mathrm{OH}^{-}$even more rapidly. The dissolution rates of phyllosilicates generally increase with increasing temperature (e.g., Carroll and Walther, 1990) in accord with the Arrhenius rate law (Nagy, 1995), and the SX tank farm sediments were elevated in temperature at the time of waste release $\left(80-100^{\circ} \mathrm{C}\right.$; White et al., 2001) and continue to be so to this day (Fig. 3c). Magnetite shows an increase in solubility above $\mathrm{pH} 9$ (Sweeton and Baes, 1970). Ferrous iron surface sites and $\mathrm{Fe}(\mathrm{II})_{\text {aq }}$ liberated through the dissolution of chlorite, magnetite, and biotite react with $\mathrm{O}_{2}$ and contribute to suboxic or anoxic conditions in groundwaters (Grenthe et al., 1992; Malmstrom and Banwart, 1997; Malmstrom et al., 1996; White and Yee, 1985).

The homogeneous reaction rate of $\mathrm{Fe}(\mathrm{II})$ with $\mathrm{CrO}_{4}^{2-}$ increases with both an increase in $\mathrm{pH}$ and temperature (Pettine et al., 1998; Sedlak and Chan, 1997). The rates become so rapid at increased $\mathrm{pH}$ that Sedlak and Chan (1997) predicted almost instantaneous reduction of $\mathrm{Cr}(\mathrm{VI})$ by excess $\mathrm{Fe}(\mathrm{II})$ above a $\mathrm{pH}$ of 7. The $\mathrm{pH}$ and temperature effect appear related to the aqueous speciation of $\mathrm{Fe}(\mathrm{II})$; hydrolysis apparently decreases the activation energy and reduction rate constants increase with added hydroxyls (e.g., $\mathrm{k}\left[\mathrm{Fe}(\mathrm{OH})_{2(\mathrm{aq})}^{\mathrm{o}}\right]>\mathrm{k}\left[\mathrm{FeOH}^{+}{ }_{(\mathrm{aq})}\right]>$ 


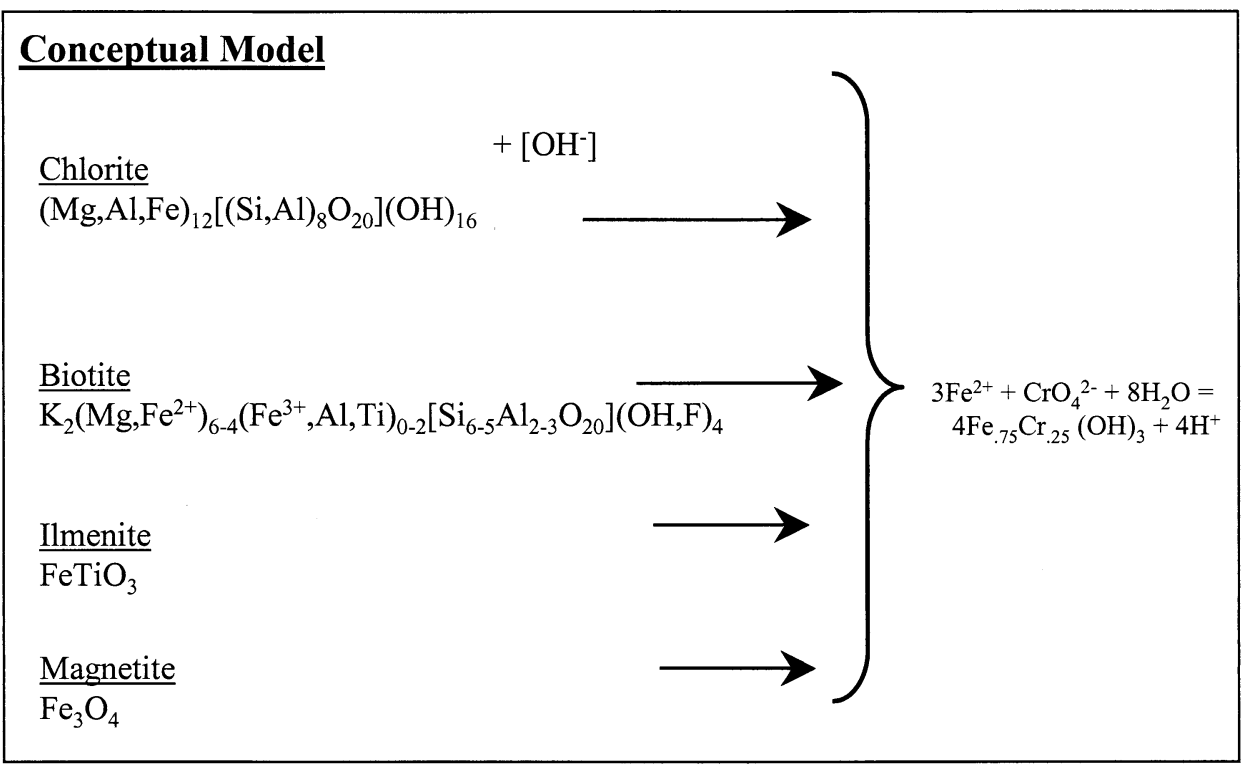

Fig. 11. A conceptual model for the waste-induced reduction of $\mathrm{Cr}(\mathrm{VI})$ in Hanford sediments. High $\mathrm{OH}^{-}$concentrations in REDOX waste are believed to facilitate dissolution of Fe(II) bearing minerals in the Hanford sediment (chlorite, biotite, ilmenite, and magnetite). Ferrous iron released by dissolution functions as a homogeneous or heterogeneous reductant of $\mathrm{Cr}(\mathrm{VI})$. The reaction ceases when $\mathrm{OH}^{-}$neutralization is complete and sediment $\mathrm{pH}$ returns to near ambient conditions. Reaction products from mineral dissolution are ignored for simplicity.

$\mathrm{k}\left[\mathrm{Fe}^{2+}{ }_{(\mathrm{aq})}\right]$; Sedlak and Chan, 1997). Information, however, is not available for the species-specific rate constants for the higher order hydrolysis species [e.g., $\mathrm{Fe}(\mathrm{OH})_{3(\mathrm{aq})}^{-}$or $\mathrm{Fe}(\mathrm{OH})_{2(\mathrm{~s})}$ that may have formed during the initial stages of neutralization of the high $\mathrm{pH}$ REDOX waste. Nonetheless, the available data on the homogeneous reduction of $\mathrm{CrO}_{4}^{2-}$ by $\mathrm{Fe}(\mathrm{II})$ suggests that $\mathrm{Fe}(\mathrm{II})_{(\mathrm{aq})}$ released by the base hydrolysis of biotite, ilmenite, magnetite, chlorite, or smectite in the Hanford sediment would have been immediately reactive with $\mathrm{Cr}(\mathrm{VI})$ unless it was first sorbed or incorporated into unreactive solid phases. Sorbed Fe(II), however, may have been equally or more reactive (Buerge and Hug, 1999).

What further distinguishes the REDOX waste scenario investigated here from past studies, in addition to elevated $\mathrm{pH}$ and temperature, is the high concentration of $\mathrm{CrO}_{4}^{2-}$ present in the waste stream (Table 1) and in vadose zone porewater (Table 2). Chromate was present as an excess oxidant. Chromate reduction generally shows a first order dependence on Fe(II) concentration (Pettine et al., 1998; Sedlak and Chan, 1997), and $\mathrm{CrO}_{4}^{2-}$ and $\mathrm{O}_{2(\mathrm{aq})}$ are competitive oxidants for $\mathrm{Fe}(\mathrm{II})$. Like $\mathrm{CrO}_{4}^{2-}$, the oxidation rate of $\mathrm{Fe}(\mathrm{II})$ by $\mathrm{O}_{2(\mathrm{aq})}$ is very rapid above pH 7 (Millero, 1989; Millero et al., 1987). One may speculate that $\mathrm{CrO}_{4}^{2-}$ and $\mathrm{O}_{2(\text { aq })}$ competed for $\mathrm{Fe}(\mathrm{II})$ released by basic mineral hydrolysis in the Hanford sediment, and that the ultimate amounts of $\mathrm{Cr}(\mathrm{VI})$ reduced were dependent on local partial pressures of $\mathrm{O}_{2(\mathrm{~g})}$ and concentrations of $\mathrm{OH}^{-}$that regulated $\mathrm{Fe}$ (II) concentrations available for reaction with $\mathrm{Cr}(\mathrm{VI})$. In support of this hypothesis, we note that Eary and Rai (1989) observed that the reduction of $\mathrm{Cr}(\mathrm{VI})$ by biotite decreased above $\mathrm{pH} 9$ in oxygenated mineral suspensions, and that the rates observed at $\mathrm{pH} 10$ and 11 were well below those noted at pH 5 and below. Eary and Rai (1989) speculated that a combination of low $\mathrm{Fe}(\mathrm{OH})_{2(\mathrm{~s})}$ solubility between $\mathrm{pH} 8.5$ and 10.5 , and rapid $\mathrm{Fe}(\mathrm{II})$ oxidation by $\mathrm{O}_{2(\mathrm{aq})}$ were responsible for the slow rates. It is probable that $\mathrm{O}_{2(\mathrm{aq})}$ was depleted in the microscopic regions surrounding dissolving mineral grains in the Hanford sediment through reaction with $\mathrm{Fe}(\mathrm{II})$, and that the resupply of $\mathrm{O}_{2}$ was mass-transfer limited. This depletion allowed for the eventual reduction of $\mathrm{Cr}(\mathrm{VI})$ in regions near mineral sources of $\mathrm{Fe}(\mathrm{II})$. Ongoing research is exploring this and related issues associated with the base-induced reduction mechanism.

We have attributed $\mathrm{Cr}(\mathrm{VI})$ reduction in the S-SX sediments to an abiotic mechanism involving basic mineral hydrolysis. However, a variety of subsurface microorganisms are known to directly (enzymatically) or indirectly (through reductant production) reduce $\mathrm{Cr}(\mathrm{VI})$ (e.g., Fendorf et al., 2000; Fredrickson et al., 2000). One might question whether such a process was operative here. A microbiological characterization was performed on samples from this borehole (Fredrickson et al., 2001). Of the samples studied here, low numbers of cultural microorganisms were found in samples SX-108-7A and 9A. Sample 7A contained a radiation resistant organism, Deinococcus radiodurans, (Fredrickson et al., 2001) that was capable of reducing $\mathrm{Cr}(\mathrm{VI})$ in lactate-amended enrichment cultures. In spite of this finding, we do not believe that there was sufficient electron donor, moisture content, or active in-situ populations to drive this reaction in the field.

\subsection{Retardation of $\mathrm{Cr}(\mathrm{VI})$}

The column studies showed that a fraction of the $\mathrm{Cr}(\mathrm{VI})$ present in the Hanford sediments $(15-43 \%)$ was sorbed or precipitated, and resistant to leaching (e.g., Fig. 8; Table 5; with the exception of 41-09-39 7ABC). Insights were sought on the chemical nature of the leaching resistant fraction by XANES/ 
XAFS, but the fluorescence of rare earth co-contaminants in the waste stream prevented accurate analysis of the $\mathrm{CrO}_{4}^{2-}$ extended fine structure. The adsorption behavior of $\mathrm{CrO}_{4}^{2-}$ at submillimolar concentrations on minerals and subsurface materials has been relatively well studied from aqueous solutions of different composition and ionic strength (Zachara et al., 1987; Zachara et al., 1988; Zachara et al., 1989). The surface complex is relatively weak and considered to be dominantly outer sphere. Adsorption is suppressed by other electrolyte anions (e.g., $\mathrm{NO}_{3}^{-}, \mathrm{HCO}_{3}^{-}, \mathrm{SO}_{4}^{2-}$ and others) that compete for surface sites. When taking the mineralogy, $\mathrm{pH}$, and surface area of the Hanford sediments into account along with the waste impacted pore water composition and past literature data, we conclude that $\mathrm{Cr}(\mathrm{VI})$ retardation through surface complexation (adsorption) to amphoteric surface sites is an unlikely cause for the noted retardation.

A more probable cause is that the high concentrations of $\mathrm{CrO}_{4}^{2-}$ present in porewater have induced precipitation. Hashemite $\left(\mathrm{BaCrO}_{4}\right)$ and the $\mathrm{BaCrO}_{4}-\mathrm{BaSO}_{4}$ solid solution $\left[\mathrm{Ba}\left(\mathrm{Cr}_{\mathrm{x}} \mathrm{S}_{1-\mathrm{x}}\right) \mathrm{O}_{4}\right.$; Prieto et al., 1997] are speculated to control $\mathrm{CrO}_{4}^{2-}$ solubility in geochemical environments where barite $\left(\mathrm{BaSO}_{4}\right)$ is present (Palmer and Wittbrodt, 1991; Rai et al., 1988), and such phases may have been important here. Both $\mathrm{Ba}^{2+}$ and $\mathrm{SO}_{4}^{2-}$ existed in the sediment porewaters and were quantified by $1: 1$ water extraction (Table 3 ). Using these data to estimate porewater $\mathrm{Ba}^{2+}$ (which ranged between $1.58 \times 10^{-6}$ to $2.00 \times 10^{-5} \mathrm{~mol} / \mathrm{L}$ ), we calculated an average ion concentration product $(\mathrm{ICP}=\log [\mathrm{Ba}]+\log [\mathrm{Cr}(\mathrm{VI})])$ of $-6.27 \pm 0.33$ for the porewater in Samples 6A through 14A. Activities were not calculated because of the attendant difficulties in doing so in these high ionic strength solutions (Fig. 3). The relatively constant value of the ICP implied a solubility constraint, but did not necessarily confirm the presence of $\mathrm{BaCrO}_{4}$. The ion concentration product was higher (more soluble) than the reported value for synthetic $\mathrm{BaCrO}_{4}$ (-9.10; Rai et al., 1988), which is a possible artifact of the high ionic strength of the water extraction that dissolved the solid phase.

Because the leaching resistant fraction appeared to be greater nearer to the tank where mineral alteration was appreciable (Table 5), it is also plausible that waste-sediment reaction induced secondary precipitation that sequestered or coprecipitated $\mathrm{Cr}(\mathrm{VI})$ within mineral interstices. Bartlett and Kimble (1976) suggested that $\mathrm{Cr}(\mathrm{VI})$ coprecipitates with $\mathrm{Al}$ oxides, but the phases and chemistry were unspecified. The REDOX wastes were believed to contain large concentrations of $\mathrm{Al}(\mathrm{OH})_{4}^{-}$(Table 1) that precipitated differentially with depth as the free $\mathrm{OH}^{-}$concentration of the supernatant moderated through mineral reaction. The concentration of these aluminous phases would decrease with depth, as does the "leachingresistant" $\mathrm{Cr}(\mathrm{VI})$ fraction. While this apparent correlation is suggestive of cause-and-effect, additional studies are needed to determine if $\mathrm{Cr}(\mathrm{VI})$ can indeed co-precipitate within secondary phases formed as products of REDOX waste-sediment reaction, including the zeolite-like phases in (Figs. 4 and 5). The relatively fast resupply of $\mathrm{Cr}(\mathrm{VI})$ during the stop-flow event was more suggestive, however, of the dissolution of a moderately soluble salt (such as $\mathrm{BaCrO}_{4}$ ), than an insoluble coprecipitate. Alternatively, the fast resupply of $\mathrm{Cr}(\mathrm{VI})$ during the stop-flow event may have resulted from the diffusion of $\mathrm{Cr}(\mathrm{VI})$ form less hydraulically active regions of the columns into preferential flow regions.

\subsection{Waste Emplacement and Future Migration}

The XANES and column studies demonstrated that there are at least three pools of $\mathrm{Cr}$ in the HLW contaminated sediments: i.) immobile $\mathrm{Cr}(\mathrm{III})$ that has been precipitated as a discrete $\left[\mathrm{Cr}(\mathrm{OH})_{3}\right]$ or solid-solution hydroxide $\left[\mathrm{Cr}_{\mathrm{x}} \mathrm{Fe}_{1-\mathrm{x}}(\mathrm{OH})_{3}\right](25-$ $71 \%$ of $\left.\mathrm{Cr}_{[\mathrm{T}]}\right)$, ii.) leaching resistant $\mathrm{Cr}(\mathrm{VI})$ that may reside as a moderately soluble salt or coprecipitate $\left(0-30 \%\right.$ of $\mathrm{Cr}_{[\mathrm{TT}}$; $0-43 \%$ of $\left.\mathrm{Cr}(\mathrm{VI})_{[\mathrm{T}]}\right)$, and iii.) water soluble/water leachable $\mathrm{Cr}(\mathrm{VI})\left(23-58 \%\right.$ of $\mathrm{Cr}_{[\mathrm{T}]} ; 57-100 \%$ of $\left.\mathrm{Cr}(\mathrm{VI})_{[\mathrm{T}]}\right)$ existing in residual porewater or as a soluble salt in pore space $\left(\mathrm{Na}_{2} \mathrm{CrO}_{4}\right)$. Generally, the water-soluble fraction increased with depth while the sorbed/precipitated fraction followed a reverse trend (Table 5). The trend in the sorbed/precipitated fraction, in turn, paralleled that of waste/base induced mineral alteration. The existence of a significant sorbed/precipitated $\mathrm{Cr}$ pool is inconsistent with the small degree of retardation noted for the $\mathrm{Cr}$ plumes relative to that for $\mathrm{NaNO}_{3}$ (Fig. 3), but is consistent with the in-situ retardation factors $\left(\mathrm{R}_{\text {-app }}\right)$ calculated from the water and acid extractions (Table 2). Even these retardation factors underestimate the attenuation degree as shown by the adjusted retardation factors ( $\mathrm{R}_{\text {-adj }}$; Table 2$)$, which were calculated using the total $\mathrm{Cr}\left(\mathrm{Cr}_{[\mathrm{T}]}\right)$ determined by XRF (Table 3$)$. Higher retardation factors (Table 2) were derived from the XRF data because acid extraction was not totally effective in dissolving sorbed $\mathrm{Cr}$ (Table 3).

We speculate that most of the $\mathrm{Cr}(\mathrm{VI})$ reduction and precipitation occurred after the primary release and migration event, which occurred in the late 1960s. Had this not occurred, greater separation would be evident between the centers of mass of $\mathrm{Cr}$ and $\mathrm{NaNO}_{3}$ consistent with the adjusted retardation factors. However, the gradient in mineral alteration noted by SEM with depth (Fig. 4) indicated that significant $\mathrm{OH}^{-}$reaction and neutralization occurred during the transport event, an unexplained inconsistency. Apparently though, the high-density REDOX waste supernatant migrated relatively rapidly through the sand textured sediments to the depths currently defined by the $\mathrm{NaNO}_{3}$ plume. The movement of this plume slowed or ceased as the source term was eliminated (through salt healing in the tank) and sediment water saturation decreased through capillarity and evaporation induced by elevated sediment temperatures. Post emplacement reduction and precipitation of the $\mathrm{Cr}(\mathrm{VI})$ resulted from solutes [e.g., $\mathrm{Fe}(\mathrm{II}), \mathrm{Ba}^{2+}$ ] liberated by rate-limited, temperature enhanced waste-sediment reactions over the extended time since waste release, or through precipitation of waste entrained solutes (such as $\mathrm{Al}$ ) induced by $\mathrm{pH}$ moderation. We do not believe that the $\mathrm{Cr}(\mathrm{VI})$ reduction reaction is still operative (except possibly in Sample 7A) because the measured $\mathrm{pH}$ values (Table 3 ) indicate almost complete neutralization of waste derived $\mathrm{OH}^{-}$. Other results soon to be published by our research team demonstrate that $\mathrm{Fe}(\mathrm{II})$ release and $\mathrm{Cr}(\mathrm{VI})$ reduction occur during the course of $\mathrm{OH}^{-}$neutralization through mineral reaction. An alternative explanation that the high in-situ retardation factors result from desiccation/ drying since emplacement because of the elevated temperature ( $\mathrm{R}$ increases with a decrease in $\theta$ if $\mathrm{K}_{\mathrm{d}}$ remains constant, Table 2) cannot explain the noted results because the decrease in $\theta$ 
would be paralleled by a decrease in $\mathrm{K}_{\mathrm{d}}$ through a solute concentration effect.

This study was motivated by concern for the fate and potential future migration of the large $\mathrm{Cr}$ inventory resulting from HLW discharge, as a regional groundwater aquifer lies approximately $15 \mathrm{~m}$ below the $\mathrm{NaNO}_{3}-\mathrm{Cr}$ plume. The Hanford environment is a semi-arid one with small amounts of infiltration and recharge to the vadose zone. A recent water balance estimate (Gee and Ward, 2001) places water drainage in the S-SX tank farm at approximately $56 \mathrm{~mm} / \mathrm{yr}$. This small amount of drainage represents only a fraction of a pore volume of the sediment column between leaked tank SX-108 and the water table. Our results indicate that under this scenario and consistent with Figure 8, only a portion of the water-soluble fraction, which itself ranges between $16-59 \%$ of $\mathrm{Cr}_{[\mathrm{T}]}$ (Table 5; excluding 41-09-39 7ABC), may ever be mobilized to groundwater. The washout profile in Figure 8, however, is expected to be even steeper at slower in-situ pore water velocities. Thus, a high concentration pulse of $\mathrm{Cr}(\mathrm{VI})$ is likely to migrate to groundwater in the future at this location unless corrective actions such as a surface barrier are employed. Importantly, however, the aqueous and total concentration of the $\mathrm{Cr}(\mathrm{VI})$ pulse could be much higher. Our results demonstrate that a minimum of $42 \%$ of the total Cr inventory is effectively immobilized as $\mathrm{Cr}(\mathrm{III})$ and $\mathrm{Cr}(\mathrm{VI})$ precipitates (Table 5) that are unlikely to dissolve appreciably and migrate to groundwater under the low drainage conditions of the Hanford Vadoz zone.

Acknowledgments-This research was supported by the U.S. Department of Energy (DOE) through the Environmental Management Sciences Program (EMSP) Contracts DE-FG07-99ER15010 (Zachara) and DE-FG07-99ER15022 (Ainsworth, Brown, and Traina) and the Hanford Science and Technology Program managed by the Groundwater Protection Program. Pacific Northwest National Laboratory (PNNL) is operated for the DOE by Battelle Memorial Institute under Contract DE-AC06-76RLO 1830. Appreciation is extended to Kathy Nagy and two anonymous reviewers whose comments improved the manuscript. Also, we acknowledge the important contribution of the characterization measurements made on the core materials by Clark Lindenmeier and Jeff Serne that were critical to hypothesis formulation. These two shared their results at an early point of synthesis allowing for the completion of this work in time to influence corrective action assessment for the $S$-SX tank farm.

Associate editor: D. J. Rimstidt

\section{REFERENCES}

Abbasi S. A. and Soni R. (1984) Teratogenic effects of chromium(VI) in the environment as evidenced by the impact of larvae of amphibian Rand tigrina: Implications in the environmental management of chromium. Int. J. Env. Stud. 23, 131-137.

Akyuz T. (1996) Strontium and cesium sorption of some Anatolian zeolites. J. Incl. Phenom. Mol. Recog. Chem. 26, 89-91.

Bargar J. R., Brown G. E. Jr, Evans I., Rowen M., Rabedeau T., and Rogers J. (2001) The hard x-ray spectroscopy molecular environmental sciences beam line at SSRL. In Speciation, Techniques, and Facilities for Radioactive Materials at Synchrotion Light Sources. (eds. T. B. Reich and B. K. Shuh) pp. 169-176. Nuclear Energy Agency, OECD. Environmental samples, including actinides, at the Stanford Synchrotron Radiation Laboratory. Proc. 2nd Euroconference and NEA Workshop on Speciation, Techniques, and Facilities for Radioactive Materials at Synchrotron Light Sources, (In press).

Barlett R. J. and James B. R. (1996) Chromium. In Methods of Soil Analysis; Part 3-Chemical Methods (ed. D. L. Sparks), Vol. 5, pp. 683-701. Soil Science Society of America.
Barlett R. J. and Kimble J. M. (1976) Behavior of chromium in soils. II. Hexavalent forms. J. Env. Qual. 5 (4), 383-386.

Bickmore B., Nagy K. L., Young J. S., and Drexler J. W. (2001) Nitrate-cancrinite precipitation in quartz sand in simulated Hanford tank solutions. Env. Sci. Tech. 35, 4481-4486.

Brigatti M. F., Franchini G., Lugli C., Medici L., Poppi L., and Turci E. (2000a) Interaction between aqueous chromium solutions and layer silicates. Appl. Geochem. 15, 1307-1316.

Brigatti M. F., Lugli C., Cibin G., Marcelli A., Giull G., Paris E., Mottana A., and Wu Z. (2000b) Reduction and sorption of chromium by $\mathrm{Fe}(\mathrm{II})$-bearing phyllosilicates: Chemical treatments and X-ray absorption spectroscopy(XAS) studies. Clays Clay Miner. 48 (2), 272-281.

Buerge I. J. and Hug S. J. (1997) Kinetics and pH dependence of chromium(VI) reduction by iron(II). Env. Sci. Tech. 31, 1426-1432.

Buerge I. J. and Hug S. J. (1999) Influence of mineral surfaces on chromium(VI) reduction by iron(II). Env. Sci. Tech. 33, 4285-4291.

Carroll S. A. and Walther J. V. (1990) Kaolinite dissolution at $25^{\circ}, 60^{\circ}$, and $80^{\circ}$ C. Am. J. Sci. 290, 797-810.

Eary L. E. and Rai D. (1988) Chromate removal from aqueous wastes by reduction with ferrous ion. Env. Sci. Tech. 22, 972-977.

Eary L. E. and Rai D. (1989) Kinetics of chromate reduction by ferrous ions derived from hematite and biotite at $25^{\circ}$ C. Am. J. Sci. 289, $180-213$.

Eary L. E. and Rai D. (1991) Chromate reduction by subsurface soils under acidic conditions. Soil Sci. Soc. Am. J. 55, 676-683.

Fendorf S., Wielinga B. W., and Hansel C. M. (2000) Chromium transformations in natural environments: The role of biological and abiological processes in chromium(VI) reduction. Intl. Geol. Rev. 42, 691-701.

Fredrickson J. K., Kostandarithes H. M., Li S. W., Plymale A. E., and Daly M. J. (2000) Reduction of $\mathrm{Fe}(\mathrm{III}), \mathrm{Cr}(\mathrm{V}), \mathrm{U}(\mathrm{VI})$, and $\mathrm{Tc}(\mathrm{VII})$ by deinococcus radiodurans R1. Appl. Env. Microbiol. 66, 2006-2011.

Fredrickson J. K., Li S., Kostandarithes H., Balkwill D., and Kennedy D. W. (2001) In Appendix D: Digest of S\&T Program Evaluations, RPP-7884 (ed. A. J. Knepp), p. D198-D212. CH2M Hill Hanford Group, Inc., Richland, WA.

Fruchter J. S., Cole C. R., Williams M. D., Vermeul V. R., Amonette J. E., Szecsody J. E., Istok J. D., and Humphrey M. D. (2000) Creation of a subsurface permeable treatment zone for aqueous chromate contamination using in situ redox manipulation. Ground Water Mon, Remed. 20(2), 66-77.

Gee G. W. and Ward A. L. (2001) Estimation of net infiltration of meteoric water at the tank farm. In Appendix D: Digest of $S \& T$ Program Evaluations, RPP-7884 (ed. A. J. Knepp), pp. D356D365. CH2M HILL Hanford Group, Inc., Richland, WA.

George G. N. and Pickering I. J. (1993) EXAFSPAK. Stanford Synchrotron Radiation Laboratory, Stanford, CA.

Grenthe I., Stumm W., Laaksoharju M., Nilsson A.-C., and Wikberg P. (1992) Redox potentials and redox reactions in deep groundwater systems. Chem. Geol. 98, 131-150.

Ilton E. S. and Veblen D. R. (1994) Chromium sorption by phlogopite and biotite in acidic solutions at $25^{\circ} \mathrm{C}$ : Insights from X-ray photoelectron spectroscopy and electron microscopy. Geochim. Cosmochim. Acta 58(13), 2777-2788.

Ilton E. S., Veblen D. R., Moses C. O., and Raeburn S. P. (1997) The catalytic effect of sodium and lithium ions on coupled sorptionreduction of chromate at the biotite edge-fluid interface. Geochim. Cosmochim. Acta 61(17), 3543-3563.

Jones T. E, Watrous R. A, Maclean G. T (2000) Inventory estimates for single-shell tank leaks in S and SX tank farms, RPP-6285, Rev. 0, CH2M HILL Hanford Group, Inc., Richland, WA.

Kent D. B., Davis J. A., Anderson L. C. D., and Rea B. A. (1995) Transport of chromium and selenium in a pristine sand and gravel aquifer: Role of adsorption processes. Water Res. Res. 31(4), 10411050.

Knauss K. G. and Wolery T. J. (1989) Muscovite dissolution kinetics as a function of $\mathrm{pH}$ and time at $70^{\circ}$ C. Geochim. Cosmochim. Acta 53, 1493-1502.

Liang T.-J. and Tsai J. Y.-C. (1995) Sorption kinetics of cesium on natural mordenite. Appl. Rad. Isot. 46, 7-12.

Lichtner P. C. (2001) Estimation of tank supernatant liquid compositions. In Appendix D: Digest of $S \& T$ Program Evaluations, RPP7884 (ed. A. J. Knepp), pp. D306-D325. CH2M HILL Hanford Group, Inc., Richland, WA. 
Lumetta G. J. and Rapko B. M. (1999) Removal of chromium from Hanford tank sludges. Sep. Sci. Tech. 34(6 \&7), 1495-1506.

Lumetta G. J., Rapko B. M., Liu J., and Temer D. J. (1998) Enhanced sludge washing for pretreating hanford tank sludges. In Science and Technology for Disposal of Radioactive Tank Wastes (eds. W. W. Schulz and N. J. Lombardo), pp. 203-218. Plenum Press.

Lytle F. W., Greegor R. B., Sandstrom D. R., Marques E. C., Wong J., Spiro C. L., Huffman G. P., and Huggins F. E. (1984) Measurement of soft X-ray absorption spectra with a fluorescent ion chamber detector. Nucl. Instr. Meth. 226, 542-548.

Malmstrom M. and Banwart S. (1997) Biotite dissolution at $25^{\circ} \mathrm{C}$ : The $\mathrm{pH}$ dependence of dissolution rate and stoichiometry. Geochim. Cosmochim. Acta 61(14), 2779-2799.

Malmstrom M., Banwart S., Lewenhagen J., Duro L., and Bruno J. (1996) The dissolution of biotite and chlorite at $25^{\circ} \mathrm{C}$ in the near-neutral pH region. J. Contam. Hydrol. 21, 201-213.

McKinley J. P., Zachara J. M., Gassman P. L., Ainsworth C. C., Arey B., McKinley S., Schaef H. T., Smith S. C., Kimberling J., Bish D. L., Chipera S. J., and Snow P. (2001a) S-SX site mineralogy. In Appendix D: Digest of S\&T Program Evaluations, RPP-7884 (ed. A. J. Knepp), pp. D10-D35. CH2M HILL Hanford Group Inc., Richland, WA.

McKinley J. P., Zeissler C. J., Zachara J. M., Serne R. J., Lindstrom R. M., Schaef H. T., and Orr R. D. (2001b) Distribution and retention of ${ }^{137} \mathrm{Cs}$ in sediments at the Hanford Site, Washington. Env. Sci. Tech. 35, 3433-3441.

Millero F. J. (1989) Effect of ionic interactions on the oxidation of $\mathrm{Fe}(\mathrm{II})$ and $\mathrm{Cu}(\mathrm{I})$ in natural waters. Mar. Chem. 28, 1-18.

Millero F. J., Sotolongo S., and Izaguirre M. (1987) The oxidation kinetics of Fe(II) in seawater. Geochim. Cosmochim. Acta 51, 793-801.

Nagy K. L. (1995) Dissolution and precipitation kinetics of sheet silicates. In Chemical Weathering Rates of Silicate Minerals (ed. A. F. White and S. L. Brantley), Vol. 31, pp. 173-233. Mineralogical Society of America.

Nyman M., Krumhansl J. L., Zhang P., Anderson H., and Nenoff T. M. (2000) Chemical evolution of leaked high-level liquid wastes in Hanford soils. Sci. Basis Nucl. Waste Manag., XXIII, pp. 225-230.

Ono B.-I. (1988) Genetic approaches in the study of chromium toxicity and resistance in yeast and bacteria. In Chrom. Nat. Hum. Env. (ed. J. O. Nriagu and E. Nieboer), pp. 351-368. John Wiley and Sons.

Palmer C. D. and Wittbrodt P. R. (1991) Processes affecting the remediation of chromium-contaminated sites. Env. Health Perspect. 92, 25-40.

Paschin Y. V., Kozachenko V. I., and Sal'nikova L. E. (1983) Differential mutagenic response at the HGPRT locus in V-79 and CHO cells after treatment with chromate. Mutat. Res. 122, 361-365.

Peterson M. L., Brown G. E. Jr., and Parks G. A. (1996) Direct XAFS evidence for heterogeneous redox reaction at the aqueous chromium/ magnetite interface. Coll. Surf. A. 107, 77-88.

Peterson M. L., Brown G. E. Jr., Parks G. A., and Stein C. L. (1997a) Differential redox and sorption of $\mathrm{Cr}(\mathrm{III} / \mathrm{VI})$ on natural silicate and oxide minerals: EXAFS and XANES results. Geochim. Cosmochim. Acta 61(16), 3399-3412.

Peterson M. L., White A. F., Brown G. E. Jr, and Parks G. A. (1997b) Surface passivation of magnetite by reaction with aqueous $\mathrm{Cr}(\mathrm{VI})$ : XAFS and TEM results. Env. Sci. Tech. 31(5), 1573-1576.

Pettine M., D'Ottone L., Campanella L., Millero F. J., and Passino R. (1998) The reduction of chromium(VI) by iron(II) in aqueous solutions. Geochim. Cosmochim. Acta 62(9), 1509-1519.

Poston T. M., Hanf R. W., Dirkes R. L., and Morasch L. F. (2001) Hanford Site Environmental Report for Calendar Year 2000. Pacific Northwest National Laboratory, Richland, WA.

Prieto M., Fernandez-Gonzalez A., Putnis A., and Fernandez-Diaz L. (1997) Nucleation, growth, and zoning phenomena in crystallizing $(\mathrm{Ba}, \mathrm{Sr}) \mathrm{CO}_{3}, \mathrm{Ba}\left(\mathrm{SO}_{4}, \mathrm{CrO}_{4}\right),(\mathrm{Ba}, \mathrm{Sr}) \mathrm{SO}_{4}$, and $(\mathrm{Cd}, \mathrm{Ca}) \mathrm{CO}_{3}$ solid solutions from aqueous solutions. Geochim. Cosmochim. Acta 61(16), 3383-3397.

Pruess K., Yabusaki S. B., Steefel C. I., and Lichtner P. C. (2001) Fluid flow, heat transfer, and solute transport at tank SX-108; A summary report on modeling studies. In Appendix D: Digest of $S \& T$ Program Evaluations, RPP-7884 (ed. A. J. Knepp), pp. D259-D276. CH2M HILL Hanford Group, Inc., Richland, WA.

Rai D., Hess N. J., Rao L., Zhang Z., Felmy A. R., Moore D. A., Clark S. B., and Lumetta G. J. (2001) Thermodynamic model for the solubility of $\mathrm{Cr}(\mathrm{OH})_{3}(\mathrm{am})$ in concentrated $\mathrm{NaOH}$ and $\mathrm{NaOH}-\mathrm{NaNO}_{3}$ solutions. J. Sol. Chem. 31(5), 343-367.

Rai D., Sass B. M., and Moore D. A. (1987) Chromium(III) hydrolysis constants and solubility of chromium(III) hydroxide. Inorg. Chem. 26, 345-349.

Rai D., Zachara J. M., Eary L. E., Ainsworth C. C., Amonette J. E., Cowan C. E., Szelmeczka R. W., Resch C. T., Schmidt R. L., Smith S. C., and Girvin D. C. (1988) Chromium Reactions in Geologic Materials. Electric Power Research Institute, Palo Alto, CA.

Rai D., Zachara J. M., Eary L. E., Girvin D. C., Moore D. A., Resch C. T., Sass B. M., and Schmidt R. L. (1986) Geochemical Behavior of Chromium Species. Electric Power Research Institute, Palo Alto, CA.

Rhoades J. D. (1996) Salinity: Electrical conductivity and total dissolved solids. In Methods of Soil Analysis, Part 3-Chemical Methods (eds. D. Sparks, et al.), pp. 417-435. Soil Science Society of America, WI

Rose D. (1977) Hydrodynamic dispersion in porous materials. Soil Sci. 123, 277-283.

Sedlak D. L. and Chan P. G. (1997) Reduction of hexavalent chromium by ferrous iron. Geochim. Cosmochim. Acta 61(11), 2185-2192.

Serne R. J., Schaef H. T., Bjornstad B. N., Williams B. A., Lanigan D. C., Horton D. G., Clayton R. E., LeGore V. L., O'Hara M. J., Brown C. F., Parker K. E., Kutnyakov I. V., Serne J. N., Mitroshkov A. V., Last G. V., Smith S. C., Lindenmeier C. W., Zachara J. M., and Burke D. B. (2001a) Geologic and geochemical data collected from vadose zone sediments from borehole SX 41-09-39 in the S/SX waste management area and preliminary interpretations. Pacific Northwest National Laboratory, Richland, WA.

Serne R. J., Last G. V., Gee G. W., Schaef H. T., Lanigan D. C., Lindenmeier C. W., Clayton R. E., LeGore V. L., Orr R. D., O'Hara M. J., Brown C. F., Burke D. B., Owen A. T., Kutnyakov I. V., and Wilson T. C. (2001b) Geologic and geochemical data collected from vadose zone sediments from borehole SX 41-09-39 in the S/SX waste management area and preliminary interpretations. Pacific Northwest National Laboratory, Richland, WA.

Serne R. J., Schaef H. T., Bjornstad B. N., Lanigan D. C., Gee G. W., Lindenmeier C. W., Clayton R. E., LeGore V. L., O'Hara M. J., Brown C. F., Orr R. D., Last G. V., Kutnyakov I. V., Burke D. B., Wilson T. C., and Williams B. A. (2001c) Geologic and geochemical data collected from vadose zone sediments from borehole 299 W23-19 in the S/SX waste management area and preliminary interpretations [SX-115]. Pacific Northwest National Laboratory, Richland, WA.

Swayambunathan V., Liao Y. X., and Meisel D. (1989) Stages in the evolution of colloidal chromium(III) oxide. Langmuir 5(6), 1423-1427.

Sweeton F. H. and Baes C. F., Jr. (1970) The solubility of magnetite and hydrolysis of ferrous ion in aqueous solutions at elevated temperatures. J. Chem. Thermodyn. 2, 479-500.

White A. F. and Peterson M. L. (1996) Reduction of aqueous transition metal species on the surfaces of Fe(II)-containing oxides. Geochim. Cosmochim. Acta 60(20), 3799-3814.

White A. F. and Yee A. (1985) Aqueous oxidation-reduction kinetics associated with coupled electron-cation transfer from iron-containing silicates at $25^{\circ}$ C. Geochim. Cosmochim. Acta 49, 1263-1275.

White M. D., Yabusaki S. B., and Pruess K. (2001) Nonisothermal multiphase fluid flow and transport: Multitank modeling in the SX tank farm. In Appendix D: Digest of S\&T Program Evaluations, RPP-7884 (ed. A. J. Knepp), pp. D277-D305. CH2M HILL Hanford Group, Inc., Richland, WA.

Zachara J. M., Ainsworth C. C., Cowan C. E., and Resch C. T. (1989) Adsorption of chromate by subsurface soil horizons. Soil Sci. Soc. Am. J. 53, 364-373.

Zachara J. M., Cowan C. E., Schmidt R. L., and Ainsworth C. C. (1988) Chromate sorption on Na-saturated kaolinite. Clays Clay Miner. 36, 317-326.

Zachara J. M., Girvin D. C., Schmidt R. L., and Resch C. T. (1987) Chromate adsorption on amorphous iron oxyhydroxide in presence of groundwater major ions. Env. Sci. Tech. 21, 589-594.

Zachara J. M., Smith S. C., McKinley J. P., Serne R. J., and Gassman P. L. (2002) Sorption to $\mathrm{Cs}^{+}$to micaceous subsurface sediments from the Hanford site. Geochim. Cosmochim. Acta 66, 193-211.

Zeissler C. J., Wight S. A., and Lindstrom R. M. (1998) Detection and characterization of radioactive particles. Appl. Rad. Isotop. 49, 9-11. 